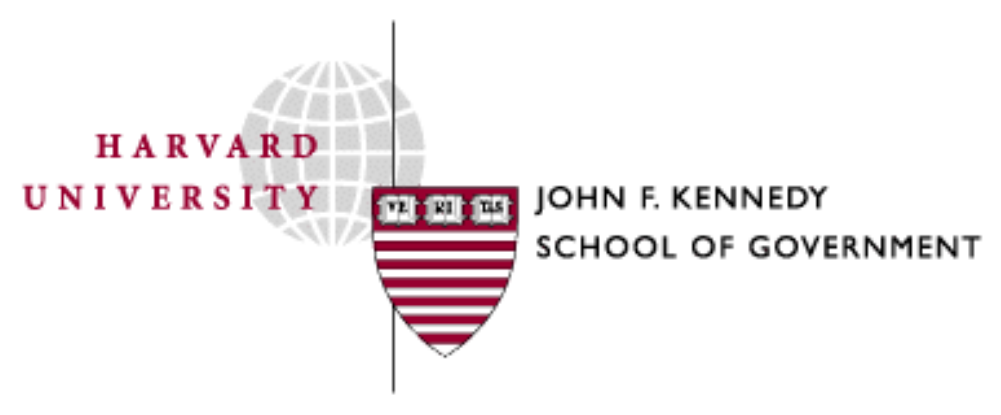

Faculty Research Working Papers Series

\title{
What Do Parents Value in Education? An Empirical Investigation of Parents' Revealed Preferences for Teachers
}

\author{
Brian A. Jacob and Lars Lefgren
}

July 2005

RWP05-043

This paper can be downloaded without charge from: http://ksgnotes1.harvard.edu/Research/wpaper.nsf/rwp/RWP05-043

or

The Social Science Research Network:

http://ssrn.com/abstract=832644

The views expressed in the KSG Faculty Research Working Paper Series are those of the author(s) and do not necessarily reflect those of the John F. Kennedy School of Government or Harvard University. Copyright belongs to the author(s). Papers may be downloaded for personal use only. 


\title{
What Do Parents Value in Education? An Empirical Investigation of Parents' Revealed Preferences for Teachers *
}

\author{
Brian A. Jacob \\ Harvard University and NBER \\ Lars Lefgren \\ Brigham Young University
}

June 2005

\footnotetext{
${ }^{*}$ We would like to thank Joseph Price and J.D. LaRock for their excellent research assistance. We thank Sue Dynarski, Steve Glazerman, Robin Jacob, Larry Katz, Asim Khwaja, Frank McIntyre and seminar participanats at Stanford University, the Kennedy School of Government, Brigham Young University and the National Bureau of Economic Research for helpful comments. All remaining errors are our own. Jacob can be contacted at: John F. Kennedy School of Government, Harvard University, 79 JFK Street, Cambridge, MA 02138; email:

brian_jacob@harvard.edu. Lefgren can be contacted at: Department of Economics, Brigham Young University, 130 Faculty Office Building, Provo, UT 84602-2363; email: l-lefgren@byu.edu.
} 


\title{
What Do Parents Value in Education? An Empirical Investigation of Parents’ Revealed Preferences for Teachers
}

\begin{abstract}
$\underline{\text { Abstract }}$
This paper examines revealed parent preferences for their children's education using a unique data set that includes the number of parent requests for individual elementary school teachers along with information on teacher attributes including principal reports of teacher characteristics that are typically unobservable. We find that, on average, parents strongly prefer teachers that principals describe as good at promoting student satisfaction and place relatively less value on a teacher's ability to raise standardized math or reading achievement. These aggregate effects, however, mask striking differences across family demographics. Families in higher poverty schools strongly value student achievement and are essentially indifferent to the principal's report of a teacher's ability to promote student satisfaction. The results are reversed for families in higher-income schools.
\end{abstract}




\section{Introduction}

This paper examines parent preferences for their child's elementary school teacher using information obtained from principals about parent requests for individual teachers. To our knowledge, this is the first study to examine the preferences of parents using information on choices within schools. This allows us to not only control for location and other factors that may be driving residential or school choice, but also allows us to explore extremely detailed teacher characteristics. In addition to standard teacher demographics such as gender, experience, certification status and educational background, we use achievement data to create a value-added measure of each teacher's ability to raise student performance. Moreover, we utilize principal survey information to create teacher measures that reflect "softer" teacher attributes that are likely to be valued by parents but are typically unobservable to the researcher (e.g., whether the teacher is adept at classroom management or is perceived as a good role model for students).

We find that, on average, parents strongly prefer teachers that principals describe as best able to promote student satisfaction, and place relatively less value on a teacher's ability to raise standardized math or reading achievement. These aggregate effects, however, mask striking differences across family demographics. Parents in low-income and minority schools strongly value student achievement and are essentially indifferent to the principal's report of a teacher's ability to promote student satisfaction. The results are reversed for families in higher-income and non-minority schools. These results are consistent with a declining marginal utility of basic math and reading achievement. Moreover, we find that parents in low-income and minority schools are substantially less likely to request any teacher. 
Several factors are important to note when interpreting our results. First, our estimates reflect parent decisions conditional on school choice. ${ }^{1}$ It is possible that parents may consider certain factors in choosing a school and other factors in choosing a teacher within a school. Recent research suggests that the variation in teacher quality within schools is much larger than the variation in teacher quality across schools (Hanushek et al. 2005). To the extent that parents recognize this fact, they may well prioritize factors such as proximity to home in choosing a school, but focus on student achievement in requesting a teacher.

Second, the parameters we estimate reflect both what parents observe and what they value. To the extent that parents have less information on a particular teacher characteristic, our estimates may understate parent preferences for this characteristic. ${ }^{2}$ In particular, one might be concerned that parents do not have good information on teachers' ability to raise student achievement. Parents may have limited access to student test scores by classroom, and even with such information they may have difficulty inferring teacher quality due to non-random assignment of students. In practice, however, several pieces of evidence suggest that parents in this district are able to observe teacher behaviors and attributes associated with student achievement gains. Most notably, those parents who arguably have the least ability to ascertain a teacher’s ability to improve student performance - i.e., parents in low-income, high minority schools - exhibit the strongest preferences for teachers with this quality. ${ }^{3}$ In addition, this pattern is evident regardless of whether one uses a principal-reported measure or a teacher value-

\footnotetext{
${ }^{1}$ There is no open enrollment system in this district so that residential location entirely determines elementary school attendance.

${ }^{2}$ This does not imply, however, that the parent must observe the actual variable we include in our regressions in order to infer preferences. For example, principal ratings are not observed by the parent but likely reflect the same teacher attributes and behaviors that parents learn about through informal channels. In this case, a significant coefficient on the principal rating suggests that both parents and principals have access to correlated information regarding teacher effectiveness.

${ }^{3}$ Of course, one can imagine some circumstances in which parents from wealthier schools are less able to observe teacher quality (e.g., if the variation in teacher quality is smaller in such schools). We explore these alternatives in greater detail below.
} 
added measure based on student achievement scores. Indeed, the results are even stronger for the principal-reported measure, which is likely to reflect teacher behaviors and attributes that are more easily observable to parents.

Third, the analysis is based on aggregate teacher request data. This limits our ability to distinguish between the following two cases: (a) parents whose children attend low-income schools have different preferences than parents whose children attend higher-income schools; and (b) low-income parents themselves (regardless the school their children attend) have different preferences than higher-income parents. To the extent that many educational decisions are made on the basis of school-level characteristics, however, this limitation is less important from a policy perspective. Finally, because parents are not required to request a teacher, our estimates reflect the preferences of the roughly 30 percent of parents who make a request. ${ }^{4}$ While it is of course impossible to know with certainty the preferences of those parents who made no request, our estimates will reflect the preferences of a particularly interesting and important group - i.e., those parents who are most involved in their children's education, and most likely to be involved in the political process and impact school policy.

Our findings suggest that what parents expect out of school is likely to depend on parent preferences and family background. To the extent that a child has already learned to read well by the second or third grade, for example, basic phonics instruction may be unappreciated by the parent. On the other hand, the parents of a disadvantaged child who is still struggling with basic literacy are likely to value the emphasis on basic skills. This implies that more and less advantaged parents may exhibit systematic differences with regards to schooling preferences even if both sets of parents have the same underlying utility functions.

\footnotetext{
${ }^{4}$ Moreover, to the extent that many parents do not have a strong preference for any particular teacher, but want their children to be in the same classroom, certain teachers preferred by a small number of parents may become focal points. In this case, our estimates may reflect the preferences of a smaller subset of parents.
} 
This has important implications for current school reform strategies. First, it suggests that communities are likely to react quite differently to accountability policies, such as those embodied in the federal accountability legislation No Child Left Behind (NCLB), depending on the demographic makeup of the children. Specifically, we would predict that higher-income communities would express greater dissatisfaction with the achievement emphasis of NCLB. Second, it suggests that school choice could lead to segregation across demographic groups driven by the preferences of the parents. At the same time, however, our findings imply that low-income families who make a request not only recognize high quality teachers, but also strongly value student achievement. This may alleviate the concerns of some that more disadvantaged students will not benefit from choice.

While our results cannot be directly compared with the findings from studies that examine parental choice of schools, our findings suggest that even the best school choice studies may be more difficult to interpret than previously realized. For example, the preference for attending racial or socially homogeneous schools that has been documented in prior literature may not reflect a desire for segregation per se, but instead may reflect an interest in a particular type of curriculum or pedagogy with the socioeconomic composition of the school merely serving as a signal of certain practices. For example, low-income families may choose to attend a school with a high proportion of other low-income families because they believe that the parents in these schools have preferences that, like their own, prioritize student achievement over student enjoyment. Conversely, high-income parents may choose to attend schools with high test scores not because those schools engage in the basic skills and test preparation that is most helpful for increasing test performance, but for completely opposite reasons - namely, because the preferences of families in those schools signal that teachers will engage in less basic skills 
instruction and offer instead a broad curriculum and activities that increase student engagement in the academic process.

The remainder of the paper proceeds as follows. In Section II, we briefly review the prior literature on parent preferences in education. In Section III, we describe our data. In Section IV, we present some preliminary reduced form estimates of the association between teacher characteristics and parent requests. In Section V, we develop a simple model of parent requests which we estimate via maximum likelihood to recover the underlying preference parameters of parents. Section VI concludes.

\section{Prior Literature}

The prior research on parent preferences falls into several categories. Most prior studies rely on surveys that directly ask parents what features they value in a school (see, for example, Lee, Croninger and Smith 1994 and Coldren and Boulton 1991). They find that parents, including lower-income respondents, highly value academic quality. The two major drawbacks of these studies are (1) parents may provide socially desirable responses, and (2) surveys do not present parents with realistic choices that require them to make tradeoffs between specific characteristics.

A second category of studies examines the actual choices made by parents. In general, these studies indicate that the location and racial/socioeconomic composition of a school are the most important factors for parents. For example, Glazerman (1998) utilized an extremely rich data set to estimate a discrete choice model of parent preferences in the Minneapolis public school choice program. He found that parents were not more likely to choose schools with high 
test scores or greater value-added, but instead preferred schools relatively close to home and ones where they were better represented ethnically and racially. ${ }^{5}$

Other studies examine the relationship between housing prices and school characteristics to assess how much parents value different aspects of schooling. In a seminal paper, Black (1999) examined house prices close to school attendance boundaries within school districts, thereby removing the influence of neighborhoods, taxes and school spending and focusing strictly on individual school characteristics. She found that parents were willing to pay 2.5 percent more for a five percent increase in student test scores. Similarly, Figlio and Lucas (2004) find that arbitrary distinctions embedded in the letter grades that schools receive on state “report cards” lead to major housing price effects, even after one accounts for underlying school achievement and other characteristics. Bayer et al. (2003) develop a comprehensive structural model for identifying preferences for school and neighborhood attributes, and estimate the model using detailed data from a restricted-use version of the Census. They find that on average households are willing to pay an additional one percent for homes - substantially lower than in prior work - when the average performance of the local school is increased by five percent. While these studies provide an idea of what parents value in their children's education, they do not allow one to separately identify which characteristics of schools are valued by parents since test scores, socioeconomic composition and other factors are very highly correlated.

Finally, several studies approach the question of parental preferences by comparing schools and students in areas with more or less opportunities for Tiebout choice. Hoxby (1999) finds that schools in MSAs with more choice offer more challenging curricula, impose stricter academic requirements and have more structured and discipline-oriented environments,

\footnotetext{
${ }^{5}$ For other examples, see Henig 1990, Lankford and Wyckoff 2000, Weiher and Tedin 2002, Schneider and Buckley 2002.
} 
suggesting that parents value these characteristics in schools. Rothstein (2003) explores parental preferences by examining how the within MSA residential location of families differs across metropolitan areas, and finds little evidence that parents choose schools for characteristics other than peer groups.

\section{Data}

The data for this study come from a mid-size school district located in the western United States. ${ }^{6}$ While the students in the district are predominantly white (73 percent), there is a reasonable degree of heterogeneity in terms of ethnicity and socioeconomic status. Latino students comprise 21 percent of the elementary population and nearly half of all students in the district (48 percent) receive free or reduced price lunch. Achievement levels in the district are almost exactly at the average of the nation $\left(49^{\text {th }}\right.$ percentile on the Stanford Achievement Test).

With the assistance of the district, we were able to collect parental requests for specific elementary school teachers during the 2003-04 and 2004-05 school years. Unfortunately, the data on individual students or families was not available in most cases, so our analysis is limited to aggregate request data (e.g., 15 parents requested Mrs. Smith, 5 parents requested Mr. Williams, etc.) ${ }^{7}$ We discuss the implications of this data limitation in Section IV, using individual request data we obtained from several schools to examine what type(s) of parents in a school make requests.

We link these parental requests to administrative files that include a variety of teacher characteristics such as age, experience, educational attainment, undergraduate and graduate

\footnotetext{
${ }^{6}$ The district has requested to remain anonymous.

${ }^{7}$ Data on parent requests is not maintained centrally by the school district. We obtained paper records from individual schools and, with the assistance of school administrators, matched the data to individual teachers, for whom demographic information was available on centralized records.
} 
institution attended, and license and certification information. We also link this data to student achievement and demographic information which allows us to create value-added measures of teacher effectiveness. Finally, we administered a survey to principals in February 2003 in which we asked them to evaluate their teachers on a variety of dimensions, providing additional information about the teachers.

We obtained parent request information for all kindergarten to sixth grade teachers in 11 of the 13 elementary schools in the district in 2003-04 and 2004-05. ${ }^{8}$ Note that this also includes a list of all teachers who received zero requests. While we have request information for kindergarten and first grade teachers, we exclude these from our main analyses since we do not have value-added or principal-report measures for these teachers. Our final sample thus consists of 251 teachers. $^{9}$

The top panel of Table I presents summary statistics for the final sample. Only 14 percent of teachers in our sample are men. The average teacher is 44 years old and has roughly 12 years of experience teaching. The vast majority of teachers attended the main local university, while 14 percent attended another instate college and 4 percent attended a school out of state. 16 percent of teachers have a MA degree or higher, and the vast majority of teachers are licensed in either early childhood education or elementary education. Finally, 10 percent of the teachers in our sample taught in a mixed-grade classroom and 3 percent were in a "split" classroom with another teacher.

\footnotetext{
${ }^{8}$ More specifically, we have information for 11 of 13 schools for at least one of the two years, 2003-04 and 200405 . We have request information from 6 of 13 elementary schools for the 2003-04 academic year and from 10 of 13 elementary schools for the 2004-05 academic year. Parent request data was not available in several schools because teacher requests were not accepted, principals failed to keep a record of such requests, or principals were uncomfortable participating in the research project (this was the case in only 1 of the 13 schools).

${ }^{9}$ We will refer to each school-classroom-year observation as a "teacher" although in a small number of cases there were two teachers in the classroom, in which case we use the average characteristics of the teachers.
} 


\section{$\underline{\text { Parent Requests }}$}

There is no formal procedure for parent requests in the district. Principals report that they assign students to classes with an eye toward balancing race, gender and ability across classrooms within the same grade. Parents submit requests during the spring or summer and principals make assignments over the summer. During our analysis period, roughly 30 percent

of parents requested a teacher each year and 84 percent of teachers received at least one parental request. Parents are also able to request that that their child not be placed with a particular teacher, which we refer to as a negative request. Only about 14 percent of teachers received any negative requests, and nearly all teachers with negative requests have at least one positive request as well. Principals report that they are generally able to honor almost all requests and, perhaps for this reason, parents have an incentive to truthfully reveal their first preference.

Parents in the district appear to have strong and varied preferences for teachers based on request data. Figure I shows the distribution of positive requests. Among those teachers receiving at least one request, the average number of requests was 8 . The interquartile range of requests is 7 , ranging from the $25^{\text {th }}$ percentile of 3 requests to the $75^{\text {th }}$ percentile of 10 requests.

While these results suggest that parents have strong preferences for particular teachers, they might also reflect differences in request policies across schools and grades. To explore this possibility, Figure II plots the distribution of the difference between the most requested and least requested teacher in each school-grade-year combination. The median difference is 10 and the $90^{\text {th }}$ percentile is extremely large at 19 . Even in the $25^{\text {th }}$ percentile, the difference is still 5.

Parent requests also appear to be quite persistent over time, suggesting that they capture some true teacher characteristic as opposed to simply fads or changing parent preferences. Figure III illustrates the correlation between requests in 2003-04 and 2004-05. Instead of using 
the number of requests, we instead use a teacher's rank within each school-year (i.e., the most requested teacher receives a 1 , the second most requested receives a 2 , etc.) to account for any changes in request policies over time. The correlation is 0.66 and is strongly significant, suggesting that parents observe something that makes them request the same teachers year after year. $^{10}$

Since our analysis will reflect the information and preferences only of those parents who make requests, it is useful to examine the characteristics of these families. To do so, we regress the fraction of parents making a positive request in a particular school-year-grade on various characteristics of the student population. Table II shows the results of these estimates. As expected, we see that requests are negatively related to the poverty level and minority concentration. The estimates in column 3, for example, imply that a ten percentage point increase in the percent of students eligible for free or reduced price lunch in the grade is associated with 5.2 percentage point fewer parents making a request. ${ }^{11}$ These results suggest that the non-financial cost of making a request is higher for parents in low-income, more highly minority schools. This may be due to language barriers, cultural differences, or information asymmetries.

\section{$\underline{\text { Principal Evaluations }}$}

To obtain subjective performance assessments, we administered a survey to all elementary school principals in February 2003 asking them to evaluate their teachers along a variety of dimensions, including dedication and work ethic, classroom management, parent

\footnotetext{
${ }^{10}$ Figure III is based on the sample of five schools for which we have request data in both 2003 and 2004.

${ }^{11}$ Other findings not shown in Table II include: (1) Conditional on student demographics, lagged student ability does not predict parental requests; (2) There is no interaction between student demographics and grade level; (3) All of the results in Table II are robust to a specifications where the dependent variable is the log-odds of parent requests (i.e., $\ln (\mathrm{p} / 1-\mathrm{p})$ ). All of these results are available from the authors upon request.
} 
satisfaction, positive relationship with administrators and ability to raise math and reading achievement (see Appendix A for a sample survey form). ${ }^{12}$ Principals were assured that their responses would be completely confidential and would not be revealed to the teachers or to any other school district employee.

The bottom panel of Table I shows the summary statistics of each rating. With an average rating of roughly 8 on a scale of 1 to 10 , it is clear that even these informal and confidential evaluations are quite lenient. At the same time, Figure IV shows that principal ratings within each school are approximately normally distributed between 6 and 10 around a mean of 8 , suggesting that the ratings do have considerable variation. While the individual item ratings are certainly correlated, many of the correlations are far lower than one, suggesting that the individual items likely reflect multiple teacher attributes (Table A1 shows the full correlation matrix). To investigate the possibility of several underlying constructs, we conducted an exploratory factor analysis. Because the principal evaluation of parent satisfaction may be highly correlated with the parent request measure, we exclude this item from the factor analysis. ${ }^{13}$

Table III shows the loadings for the three factors produced by this factor analysis. The first factor clearly measures student satisfaction, with high loadings on principal ratings of student satisfaction and teacher as role model. The second factor appears to capture what might be described as traditional "teaching ability,” with high loadings on classroom management,

\footnotetext{
${ }^{12}$ In this district, principals conduct formal evaluations annually for new teachers and every third year for tenured teachers. However, prior studies have found such formal evaluations suffer from considerable compression with nearly all teachers being rated very highly. These evaluations are also part of a teacher's personnel file and it was not possible to obtain access to these without permission of the teachers.

${ }^{13}$ These factors were derived from a Maximum Likelihood factor analysis method limited to three factors with a Promax rotation. As an additional check, we create a second set of principal measures that are purged of the parent satisfaction information by regressing the factors created above on the parental satisfaction item. We then use the residuals from these regressions as factors that are by construction orthogonal to the principal's view of parent satisfaction. The results, shown in Table IX, are comparable.
} 
organization and ability to influence student math and reading scores. The third factor captures a teacher's collegiality, with high loadings on the items that ask principals to assess the teacher's relationship with colleagues and administrators.

\section{$\underline{\text { Student Achievement Measures of Teacher Effectiveness }}$}

In this district, elementary students take a set of "Core” exams in reading and math in grades 1 to $8 .^{14}$ These multiple-choice criterion-referenced exams cover topics that are closely linked to the district learning objectives and goals. While student achievement results have not been directly linked to rewards or sanctions until recently, the results of the Core exams are distributed to parents and published annually and both teachers and principals pay considerable attention to the scores.

In order to capture a teacher's effectiveness, we create value-added measures of each teacher's contribution to student performance. Here we present a brief discussion of these measures. Appendix B provides a more detailed discussion of related identification and estimation issues.

The primary challenge in constructing consistent estimates of teacher effectiveness using student achievement data is that students are generally not randomly assigned to classes. Following the standard practice in this literature, we estimate value-added models that control for a wide variety of observable student and classroom characteristics including prior achievement measures and, in some specifications, student fixed effects (see, for example, Aaronson et al. 2004, Rockoff 2004, Hanushek et al. 2005). Specifically, we estimate the following model:

$$
y_{i j k t}=C_{j t} \mathrm{~B}+X_{i t} \Gamma+\psi_{t}+\phi_{k}+\delta_{j}+\alpha_{j t}+\varepsilon_{i j k t}
$$

\footnotetext{
${ }^{14}$ Students in select grades have recently begun to take a science exam as well. The district also administered the Stanford Achievement Test (a national, norm-referenced exam) to students in grades three, five and eight over this period.
} 
where $i$ indexes students, $j$ indexes teachers, $k$ indexes school, and $t$ indexes year. The outcome measure, $y$, is a student's score on a math or reading exam. The scores are reported as the percentage of items the student answered correctly, which we normalize to be mean zero and with a standard deviation of one within each year and grade.

The vector $X$ consists of the following student characteristics: age, race, gender, freelunch eligibility, special education placement, limited English proficiency status, prior math achievement, prior reading achievement, and grade fixed effects. $C$ is a vector of classroom measures that include indicators for class size and average student characteristics. $\psi_{t}$ and $\phi_{k}$ are a set of year and school fixed effects respectively. Teacher $j$ 's contribution to student performance is captured by the $\delta_{j}$ 's. $\alpha_{j t}$ is an error term that is common to all students in teacher $j$ 's classroom in period $t$ (e.g., adverse testing conditions faced by all students in a particular class such as a barking dog). $\varepsilon_{i j k t}$ is an error term that takes into account the student's idiosyncratic error. In order to properly account for the error structure described above, we estimate specification (1) using OLS and then correct the standard errors for correlation within teacher*year using the method suggested by Moulton (1990). ${ }^{15}$

All of the results presented in this paper are robust to a variety of alternative specifications of equation (1). Perhaps most importantly, value-added models that include student fixed effects and time-varying measures of teacher experience yield comparable results (see Appendix B). The fact that we obtain nearly identical results using value-added measures that incorporate student fixed effects provides additional reassurance that our measures provide

\footnotetext{
${ }^{15}$ Another possibility would be to use cluster-corrected standard errors. However, such standard errors cannot be computed for teachers that appear in the sample for a single year. Additionally, the estimated standard errors can behave very poorly for teachers that are in the sample for a small number of years.
} 
consistent estimates of teacher performance. ${ }^{16}$ Similarly, we obtain comparable results if we use a normalized gain score to account for the fact that it may be easier to make achievement gains at different points in the ability distribution. ${ }^{17}$

A second concern is that because our value-added measures will be estimated with error they will suffer from attenuation bias when used as independent variables in a regression. To obtain consistent estimates of teacher value-added, we construct empirical Bayes (EB) estimates of teacher quality which we use in the analysis instead of the estimated value-added measures. This approach was suggested by Kane and Staiger (2002) for producing efficient estimates of school quality, but has a long history in the statistics literature (see, for example, Morris, 1983) and is closely related to the errors-in-variables approach that allows for heteroskedastic measurement error outlined by Sullivan (2001). Appendix C discusses the statistical properties of the EB estimates in greater detail.

\section{Empirical Strategy}

In this section, we first describe how one can estimate the reduced form relationship between parent requests and teacher characteristics in an OLS framework. We then explain the shortcomings of this approach and develop a simple model of parent requests that allows us to recover the underlying preferences of the parents.

\footnotetext{
${ }^{16}$ We choose not to make these the focal point of the analysis because (1) it would require dropping a small subset of teachers for whom we only observe one year of student achievement data and (2) it is quite difficult to adequately account for estimation error in the value-added in a student fixed effect model. This is due to the fact that because the student fixed effects are imprecisely estimated, the estimation error of the value-added measures has a fairly high correlation across teachers within a specific school.

${ }^{17}$ While we make use of extremely rich panel data on student achievement, the value-added specification described above has limitations nonetheless. As Todd and Wolpin (2003) point out, even if one is not concerned about omitted variables (e.g., when students and teachers are randomly assigned to classes), the $\delta_{j}$ will generally not capture the impact of teacher $j$ alone, but will also incorporate the effects of optimizing behavior on the part of families. For example, if a child gets randomly assigned to a poor teacher, her parents may spend more time helping the child with schoolwork or enroll her in an after-school program.
} 
The Reduced Form Relationship between Parent Requests and Teacher Characteristics

We estimate the simple reduced form relationship between teacher characteristics and parent requests via OLS with the following specification:

$$
y_{j k t}=\text { demo }_{j t} \mathrm{~B}_{\text {demo }}+v a_{j} \mathrm{~B}_{v a}+\text { principal }_{j} \mathrm{~B}_{\text {principal }}+\gamma_{k g t}+\varepsilon_{j k t}
$$

where $y_{j k t}$ measures the requests received by teacher $j$ in school $k$ in year $t$, demo ${ }_{j t}$ includes teacher background characteristics such as experience and educational background as well as classroom characteristics such as whether the teacher taught a mixed-grade class that year, $v a_{j}$ is the value-added measure of teacher effectiveness in raising student achievement described in the

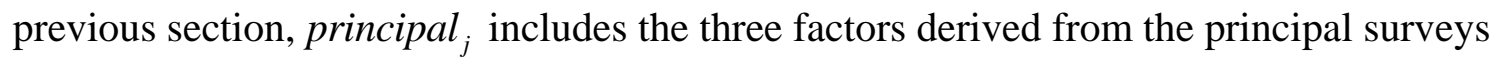
described in the previous section, and $\gamma_{k g t}$ is a vector of fixed effects for each school-grade-year combination. To account for heteroskedasticity in parent requests due to school size and variation in school policies, we normalize the number of requests by subtracting the average number of requests for a particular school-grade-year and dividing by the number of students in the cohort (i.e., the total number of parents who could have made a request). Our estimates will thus capture how particular characteristics influence the percent of parents requesting a particular teacher. The inclusion of fixed effects for school-grade-year ensures that our identification comes from variation within the relevant choice set facing parents. Finally, we cluster the standard errors by teacher to account for the fact that we observe certain teachers over multiple years. 


\section{$\underline{\text { A Structural Model of Parent Preferences for Teachers }}$}

While the reduced form approach described above is attractive in its simplicity, it has several important limitations. First, the reduced form estimates do not account for the fact that a teacher's market share of parent requests is likely to respond differently to teacher quality based on the number of teacher choices available. In a highly fragmented market, for example, we might expect a marginal change in teacher quality to have a smaller absolute effect on that teacher's share than in a market with only two options. Thus, while the OLS coefficients may yield a good approximation to the average effect of a particular characteristic on the market share, they may well perform poorly when examining grades with more or fewer teacher options than average. In addition, the reduced form strategy fails to take into account that the sum of the market shares (including the no request option) must necessarily lie between zero and one, which is likely to result in reduced statistical efficiency and predicted market shares that fall outside the interval between zero and one. Given our limited sample size, this is an important consideration.

Perhaps most importantly, the reduced form model does not allow one examine how parent preferences or the cost of making a request vary across demographic groups. This is because the costs of making a request will affect both the average number of requests as well as the relationship between requests and teacher attributes. For example, if the cost of making requests is high for low-income families, we would expect these families to make few requests and to be less responsive to any particular teacher characteristic. In this case, the reduced form coefficient of the interaction between parent income level and a teacher characteristic will reflect both preferences for the characteristic as well as the cost of making a request. A structural model will allow us to separately identify these factors. 
While the approach we outline below is very similar to a typical conditional logit discrete choice model, it differs from the standard model in several ways owing to the nature of the choice problem we study and the data we utilize. In particular, our estimation method must account for the fact that (1) we only have aggregate counts of parent requests rather than parent level request information, (2) the number of choice options varies across individuals depending on how many classes are offered in a particular school-grade-year, and (3) the expected teacher quality associated with making no request must be modeled as a function of the quality of all teachers in the choice set. ${ }^{18}$

We begin by assuming that the quality, $q_{j, s}$, of teacher $j$ in school*grade $s$ is a linear function of observed (by both us and the parents) teacher characteristics $X_{j, s}$ :

$$
q_{j, s}=X_{j, s} \beta
$$

In our case, the vector $X$ includes teacher demographics such as education and experience, valueadded measures, and principal-reported evaluations of the teacher, which reflect typically unobservable (to the econometrician) teacher attributes.

We next assume that there is some cost of making a request,

$$
c_{s}=Z_{s} \gamma,
$$

where $\mathrm{Z}$ includes school and grade level covariates $Z_{s} \cdot{ }^{19}$ In our baseline specification, we assume that the cost of making a request is a function of the child's grade and school (i.e., the

\footnotetext{
${ }^{18}$ In these respects, our approach is related to a larger industrial organization literature on the estimation of preference parameters and demand elasticities based on aggregate market shares and distributions of consumer characteristics (see, for example, Berry, Levinsohn, and Pakes, 1995). The model we develop is similar to the Berry-Levinsohn-Pakes (BLP) models common in IO, but is simpler than many recent applications of BLP-type models which incorporate additional complexity in an effort to calculate reasonable own and cross-price elasticities of demand. Because the current paper doesn't examine these issues, we use a simpler framework.

${ }^{19}$ With individual data, we would of course have the cost be a function of student or parent characteristics. This is not generally possible with the data available to us.
} 
vector $Z$ will include a set of grade fixed effects and school fixed effects). ${ }^{20}$ This assumption is motivated by the possibility that school administrators may have different informal policies regarding requests, and that requests may be more or less acceptable for children of different ages. $^{21}$

The utility parent, $i$, receives from requesting teacher $j$ is given by that teacher's quality, minus some cost, $c_{s}$, plus an idiosyncratic utility component, $\varepsilon_{i j s}$, that captures the idiosyncratic match quality between the teacher and the child. Assuming that every parent request is granted and that parent utility is linear in quality and cost, we can write the utility associated with parent $i$ requesting teacher $j$ as:

$$
U_{i, j, s}=X_{j, s} \beta-Z_{s} \gamma+\varepsilon_{i, j, s} .
$$

We will assume that this utility component is i.i.d. from a type 1 extreme value distribution. ${ }^{22}$

If a parent makes no request, we will impose that the expected teacher equals the average teacher quality in the parent's choice set. Essentially, we assume that parents believe that if they make no request their child has an equal probability of being assigned to any teacher in the choice set. Hence, the utility associated with no request equals the average teacher quality (not including the idiosyncratic match components) plus a type 1 extreme value disturbance, $\varepsilon_{\text {no }}$, that can be interpreted as the idiosyncratic utility benefit of not making a request. ${ }^{23}$

\footnotetext{
${ }^{20}$ In Table VIII, we show that our results are robust to including school-grade-year fixed effects in the cost function. ${ }^{21}$ Note that the grade and school fixed effects in the cost equation implicitly capture much of the impact of family demographics on the average number of requests. In our baseline specification, we do not include separate measures of family demographics. However, we explicitly examine the role of family demographics in the subsequent models discussed below.

${ }^{22}$ The c.d.f. of this distribution is given by $F\left(\varepsilon_{i, j, s}\right)=\exp \left(-e^{-\left(\varepsilon_{i, j, s}-\mu\right)}\right)$, where $\mu$ is a location parameter. The mean of the idiosynctratic utility term equals $\mu+.5772$. This mean is not identified since it affects the utility of all options symmetrically. Thus, one can assume that $\varepsilon_{i j s}$ is mean zero without loss of generality.

${ }^{23}$ In addition to the idiosyncratic utility associated with each teacher, there is also an idiosyncratic cost associated with making any request. One can think of the negative of this cost as the idiosyncratic benefit of not making a request. Since what matters is not the level of utility of each choice but rather the difference in utility between any
} 


$$
U\left(\text { no__request }_{i s}\right)=\frac{\sum_{k=1}^{K} X_{k s} \beta}{K}+\varepsilon_{i, n o, s} \text {, }
$$

where $K$ is the number of teachers in the choice set. ${ }^{24}$

Of course, it is possible that sophisticated parents may recognize that their child is less likely to be assigned to a popular teacher if the parent does not submit a request. In Table IX, we show that our results are robust to changing this aspect of the model, and instead assuming that the expected teacher quality equals the weighted average of teacher quality in the parent's choice set where the weights correspond to the number of vacancies in a teacher's class. For example, if one of three teachers in a particular grade is always oversubscribed and the other two teachers receive an equal number of requests, then a parent who does not make a request will expect his or her child to receive the average quality of the two less popular teachers.

If each parent chooses whichever alternative yields the highest utility, a teacher's expected market share and the probability that any given family selects teacher $j$ is given by: $:^{25}$

$$
E\left(\text { share }_{j, s}\right)=\operatorname{Pr}(\text { request }=j)=\frac{\exp \left(X_{j, s} \beta-Z_{s} \gamma\right)}{\exp \left(\frac{\sum_{k=1}^{K} X_{k, s} \beta}{K}\right)+\sum_{k=1}^{K} \exp \left(X_{j, s} \beta-Z_{s} \gamma\right)} .
$$

The no request share is:

two choices, it is irrelevant whether the idiosyncratic cost of making a request is included in the "no request" option or in every teacher request option.

${ }^{24}$ This framework imposes that the idiosyncratic utility terms for teachers average to zero within each choice set for each parent. Because the mean of the idiosyncratic utility terms is not identified, one can assume that it equals zero without loss of generality. Imposing that these idiosyncratic terms average to zero within a finite sample is a stronger assumption.

${ }^{25}$ See McFadden (1973) for a proof. 


$$
E\left(\text { share }_{n o, s}\right)=\operatorname{Pr}(\text { request }=n o)=\frac{\exp \left(\frac{\sum_{k=1}^{K} X_{k, s} \beta}{K}\right)}{\exp \left(\frac{\sum_{k=1}^{K} X_{k, s} \beta}{K}\right)+\sum_{k=1}^{K} \exp \left(X_{j, s} \beta-Z_{s} \gamma\right)} .
$$

Given the assumptions above, the probability that we observe a particular distribution of requests in a grade is given by:

$$
\begin{aligned}
& \operatorname{Pr}\left(\text { num }_{1}=n_{1}, \text { num }_{2}=n_{2}, . ., \text { num }_{\text {no }}=n_{\text {no }}\right)= \\
& A \operatorname{Pr}(t=1)^{n_{1}} \operatorname{Pr}(t=2)^{n_{2}} \ldots \operatorname{Pr}(t=n o)^{n_{\text {no }}}
\end{aligned}
$$

where num $_{i}$ is a variable corresponding to the number of parents selecting teacher $i, n_{i}$ is the particular realization of this variable, and $A$ is a constant that forms part of the multinomial distributions and simply shows the number of different ways in which a particular combination of teachers could be selected. This constant varies on the basis of the number of choices available and the aggregate counts we observe. Because it is not a function of the probabilities themselves, we can ignore it for the purposes of estimation.

It is then straightforward to identify the preference and cost parameters using maximum likelihood. Using equation (9), we can find the probability of observing a particular set of aggregate choices in each grade*school*year combination. Note that these probabilities are a function of preference and cost parameters of our model. We then multiply the probabilities for each grade-school-year combination to determine the probability of observing the entire set of aggregate choices that we find in the data. This product gives us our likelihood function and allows us to estimate the model. 
To this point, we have assumed that the idiosyncratic error terms are independent within each choice set. This is unlikely to be the case as teachers differ in both observable and unobservable ways. Because of this, the estimation method may yield standard errors that are significantly understated. Furthermore, some teachers appear in multiple years in our dataset, further complicating statistical inference. To address these problems, we bootstrap the standard errors, clustering at the school-grade level. This takes into account unobserved systematic differences across teachers as well as persistence in unobserved teacher quality. ${ }^{26}$

While we do not know which parents made each request, we can take advantage of the aggregate demographic information we have for each grade-school-year combination to estimate the differences in costs and preferences across different types of individuals. This approach has been used extensively in the industrial organization literature to estimate preference parameters and demand elasticities based on aggregate market shares and distributions of consumer characteristics (see, for example, Berry, Levinsohn, and Pakes, 1995). The intuition is that by examining how the relationship between teacher characteristics and requests changes with the fraction of, for example, low-income families in the grade, we can identify how the structural parameters vary with income.

More specifically, suppose we have two types of families, $l$ and $h$. Each type has different parameters for both their utility and cost functions. If this is true, the expected market share of teacher $j$ will equal:

\footnotetext{
${ }^{26}$ To the extent that teachers change grades across years, the clustering procedure may not fully account for the nonindependence of the utility terms across years for a specific teacher. Fortunately, nearly all teachers teach the same grade in all years.
} 


$$
\begin{gathered}
E\left(\text { share }_{j, s}\right)=\omega_{s}^{h} \frac{\exp \left(X_{j, s} \beta_{h}-Z_{s} \gamma_{h}\right)}{\exp \left(\frac{\sum_{k=1}^{K} X_{k, s} \beta_{h}}{K}\right)+\sum_{k=1}^{K} \exp \left(X_{j, s} \beta_{h}-Z_{s} \gamma_{h}\right)} \\
+\left(1-\omega_{s}^{h}\right) \frac{\exp \left(X_{j, s} \beta_{l}-Z_{s} \gamma_{l}\right)}{\exp \left(\frac{\sum_{k=1}^{K} X_{k, s} \beta_{l}}{K}\right)+\sum_{k=1}^{K} \exp \left(X_{j, s} \beta_{l}-Z_{s} \gamma_{l}\right)},
\end{gathered}
$$

where the subscripts denote the type of family making the request and $\omega_{s}^{h}$ represents the share of type $h$ families within the school*grade, s. Though theoretically, we could identify how school and grade affected the cost of making a request separately for families in each of the two groups, in practice there is insufficient variation in family demographics across grades within a school to do so. For this reason, we will constrain the school and grade fixed effects to the same for each group. We will allow the cost of making a request to vary only by a constant across groups. Even this parameter will be estimated with insufficient precision to draw strong conclusions, however.

While the model described above captures many of the essential features of the parent request decision, it does have several limitations. First, we assume that all requests are honored. While this is not strictly true, our discussions with principals suggest that the vast majority of requests are granted so this assumption is unlikely to affect the main conclusions of our analysis. Second, as is the case in all conditional logit models, our assumption of independent errors implies an assumption regarding the Independence of Irrelevant Alternatives (IIA). In settings where certain choices are thought to be extremely good substitutes for each other (e.g., a red bus and a blue bus), this assumption is particularly unrealistic. To the extent that teachers are 
unlikely to be close substitutes to each other, this assumption is less problematic. ${ }^{27}$ Moreover, while the IIA assumption is particularly problematic for predicting market shares, it does not necessarily introduce substantial bias into parameter estimates (Glazerman 1998).

\section{Limitations of Using Aggregate Request Data}

While the use of aggregate data will not affect our inferences regarding the average preference parameters in the population, it does limit our ability to examine variation in parent preferences across individual demographic characteristics. ${ }^{28}$ Ideally, in order to identify how family preferences vary with demographics, one would interact characteristics of the requested teacher with characteristics of the requesting parent. As explained above, it is possible to leverage information regarding the distribution of demographic characteristics across schoolgrade-years to examine these interactions. This approach has two limitations, however. First, because we use aggregate data, we know the characteristics of a requesting parent only probabilistically. This reduces the efficiency of the resulting parameter estimates. Second, aggregate data limits our ability to distinguish between the following cases: (a) parents whose children attend low-income schools have different preferences than parents whose children attend higher-income schools; and (b) low-income parents themselves (regardless the school their children attend) have different preferences than higher-income parents. ${ }^{29}$ To the extent that

\footnotetext{
${ }^{27}$ In the industrial organization literature, researchers are particularly concerned with this aspect of the discrete choice models. If a consumer's utility function is simply composed of a small number of observable components and an independent error, then as the price of a good rises the model predicts substitution towards other popular products regardless of their similarity to the original product. Berry, Levinsohn and Pakes (1995) propose a model with random coefficients in the utility function. This type of model predicts that as the price of one good rises, consumers will substitute toward other goods with similar observable characteristics.

${ }^{28}$ To see this, note that the teacher is the relevant unit of observation in our analysis. Assuming that we have not omitted any important teacher characteristics and the functional form of the included covariates is correct, our estimates will be unbiased.

${ }^{29}$ More generally, if one uses aggregate data, there is a choice of two identifying assumptions with regard to estimating the relationship between demographics and preferences. First, one can assume that unobserved
} 
many educational policy decisions are made at the school level, however, this limitation may not be particularly important from a practical standpoint. ${ }^{30}$

\section{Results}

Having outlined our estimation strategy, we will now present and discuss our findings. We begin by presenting OLS estimates of the relationship between parent requests and teacher characteristics, but quickly move to the structural estimates described above. A more extensive set of OLS results, that includes interactions between family demographics and parent choices, is presented in Appendix D. All of the results from the OLS models are consistent with the main structural estimates presented here.

\section{$\underline{\text { Reduced Form Estimates }}$}

Table IV presents the estimates from equation (2) where the outcome measure is the normalized number of positive requests for each teacher. ${ }^{31}$ Column 1 focuses teacher demographics and aspects of classroom organization. We observe that more experienced receive more requests than first year teachers or teachers who are new to the school. Interestingly, we

preferences for teacher characteristics are not systematically correlated to neighborhood demographics. This would be true if, for example, families were randomly assigned to neighborhoods. In this case, the method we describe above will perfectly identify the average preferences of high-income (non-minority) and low-income (minority) families. An alternative assumption is that there exists perfect Teibout sorting to neighborhoods on the basis of preferences for educational outputs. In this case, all families within a school have the same preferences and average demographics are simply a proxy for what one might describe as community values. Under this assumption, one can use aggregate data to observe how community preferences vary with average demographics. Of course, the truth is likely to be some combination of these two extremes and without individual-level data, one cannot test between them.

${ }^{30}$ In addition, the use of aggregate requires that we assume that families within a particular demographic group are homogenous (except for idiosyncratic preference and cost shocks). It is possible, however, that non-free lunch children in a disadvantaged school differ systematically from non-free lunch children in a wealthy school. To the extent that this is true, our estimates of the differences in preferences and costs between different groups may be overstated. They will, however, have the correct sign and show approximate differences in the parameters of interest.

${ }^{31}$ Specifications that incorporate information on negative requests yield comparable results (see Table IX). 
also find some evidence that parents have preferences regarding certain aspects of classroom organization. For example, parents appear to dislike mixed-grade classrooms, which are generally created when there are not enough children enrolled in a particular grade level to justify a new class composed entirely of students from that grade. In fact, teachers in these mixed-grade classrooms receive 7 percentage points fewer requests than their colleagues. This is consistent with the evidence that mixed-grade classrooms reduce student achievement (see Sims, 2005). Principals in the district indicate teachers in these classrooms often teach one grade and ask a teacher's aide to teach the other grade, particularly in subjects such as math and science where the material varies across grades and teaching a heterogeneous ability group is difficult. To the extent that parents are aware of this arrangement, one can easily imagine why such classes are unpopular.

In column 2, we show the relationship between teacher value-added and parent requests. The point estimate indicates that teachers with higher value-added measures receive more requests. While the estimates are not significant, the magnitude implies that a one standard deviation increase in teacher value-added is associated with roughly 1.2 percentage points more parent requests. Given that the average teacher receives requests from roughly 9.2 percent of parents, this reflects a 13 percent effect. In column 3, we see that parents are significantly more likely to request teachers who principals rate highly in terms of raising student achievement. Indeed, a one standard deviation increase in a teacher's achievement rating is associated with a 4.2 percentage point (45 percent) increase in parent requests. Column 4 shows that parents also place an extremely high value on the ability of teachers to make their children happy. A one standard deviation increase in the student satisfaction rating is associated with a 5.5 percentage point (53 percent) increase in parent requests. 
The specification in column 5 includes all of the principal measures together with the estimated value-added. We see that the parent satisfaction measure is more highly correlated with parent requests than the achievement measure. In addition, the principal achievement measure is more strongly related to parental requests than the value-added measure, which indicates either that parents prefer the qualities captured in the principal measure more than the value-added measure or that parents can more easily observe the qualities identified by the principal. To the extent that the principal measure includes factors such as classroom organization and management, the later explanation seems compelling. ${ }^{32}$ In column 6, we show results from a specification in which we include teacher demographics, value-added measures, and the principal evaluation factors. The results are substantively the same, though the coefficients on a number of the teacher demographic variables have fallen in magnitude.

Column 7 of Table IV shows the estimates of the teacher quality parameters from our structural model. The average marginal effects of each attribute, shown in the square brackets, are computed by calculating the marginal effect for each individual and averaging across all observations. We see that the structural model produces results quite similar to the reduced form approach. Most importantly, the relationship between parent requests and teacher attributes that capture educational outputs such as student achievement and satisfaction remains strong.

\footnotetext{
${ }^{32}$ Interestingly, we also see that teachers who the principal rates as better able to get along with colleagues receive fewer requests from parents. This is consistent with principals providing systematically biased evaluations of teacher attributes. Suppose, for example, that conditional on actual ability to raise standardized test scores a principal gives higher evaluations to teachers she likes. In this case, we expect that between two teachers with the same principal-rated instructional ability, the better-liked teacher will be less effective at raising student achievement. Jacob and Lefgren (2005) explore this issue in greater detail.
} 


\section{$\underline{\text { Main Structural Estimates }}$}

Having established the baseline results for the structural model, we now turn to the interaction between demographics and parent preferences. For the reasons mentioned earlier, we focus on the coefficients from our structural model. We allow the preference parameters to vary arbitrarily across group and allow the cost of making a request to vary across demographic groups, grades and schools. Doing so allows the probability of selecting a particular teacher to vary arbitrarily with the demographic makeup of the class. The demographic characteristics we consider include the child's eligibility for free or reduced price lunch, ethnic/racial classification, and prior achievement level. For the sake of parsimony, the models described below limit the teacher characteristics to covariates that reflect two critical education outputs - student achievement and student satisfaction - though we obtain comparable results from models that include additional teacher characteristics (see Table IX). ${ }^{33}$

To provide a basis for comparison, the first column in Table V shows estimates where the preference and cost parameters do not vary across groups. As before, we find that parents have a strong preference for teachers who promote student satisfaction and a relatively weak but statistically significant preference for teachers who promote student achievement. Specifically, a one standard deviation increase in the student satisfaction measure will result in a teacher receiving 3.9 percentage points (42 percent) more requests whereas a one standard deviation increase in the student achievement measure will result in a teacher receiving 1.5 percentage points (16 percent) more requests.

\footnotetext{
${ }^{33}$ Of course, it is possible to examine whether preferences for other teacher characteristics such as experience or gender vary with family demographics. However, it is difficult to interpret these results because it is unclear what educational outputs these characteristics may capture, and whether this would be consistent across demographic group.
} 
Columns 2-10 in Table V come from specifications that allow the preferences parameters to vary by family demographics. Assuming that all parents can observe teacher behaviors and attributes that are correlated with these characteristics, the estimates thus reflect the preferences of different groups of parents. It appears that families who are not eligible for free lunch strongly value parent satisfaction and are essentially indifferent to the principal's report of a teacher's ability to increase student achievement. The situation is reversed for the parents of children who are eligible for free lunch. These results are highly significant.

These results are echoed when we examine the preferences of minority and non-minority families. In particular, minority families value a teacher's ability to increase achievement while non-minority families appear to care only about student satisfaction. The same picture emerges when we look at the requests of parents whose students are in the top and bottom half of the initial achievement distribution. ${ }^{34}$ In all three comparisons, the differences in the preference for student satisfaction are significant at the 5 percent level; the differences in the preference for principal-reported achievement factor are generally significant at the 10 percent level or better.

To examine the robustness of this result, Table VI presents estimates from models that include the principal measure of student satisfaction, but replace the principal measure of a teacher's effectiveness at raising student achievement with our value-added measure of teacher effectiveness. The results are comparable to those presented above. That is, low-income and minority parents care more about student achievement and much less about student satisfaction while higher-income and non-minority parents have the opposite preferences.

\footnotetext{
${ }^{34}$ As noted earlier, we use test scores from the prior year to determine the percent of students scoring in the top half of the district distribution in a school-grade-year. Because we do not have student test scores for the 2003-04 school year, we use test scores for the 2002-03 school year to calculate the prior ability of the cohorts entering in 2004-05. Unfortunately, we do not have first grade test scores for 2002-03. For this reason, we must exclude second grade classes in both 2003-04 and 2004-05 and third grade classes in 2004-05 from the analyses shown in columns 8-10 (in both Table VII-A and VII-B). This is one reason that the reduced precision of these results.
} 
The fact that parents of disadvantaged children appear to care about a teacher's ability to increase achievement more than student satisfaction is consistent with a decreasing marginal utility of student achievement. If all parents have a strictly concave function defined over student achievement and student happiness, to the extent that high-income and non-minority parents have children with a higher baseline level of achievement, we expect that on the margin child happiness will be more valued than further achievement gains in school.

\section{$\underline{\text { Sensitivity Analyses }}$}

The results presented above suggest that parents in lower vs. higher-income schools have quite different preferences for their children's education. In this section, we explore the robustness of this finding.

First, one might be concerned that the level or variance of teacher quality differs substantially across schools and is associated with family demographics in a way that raises doubt about the interpretation presented here. For example, it may be that the average teacher's ability to raise student achievement is sufficiently high in advantaged schools that parents do not need to focus on student achievement. Similarly, one might speculate that there is so little variance in the teacher achievement measures in higher-income schools that parents believe that all teachers are effectively equal along this dimension and thus not place any weight on it in choosing a teacher. Both stories would explain the pattern of results we find without implying differential preferences for achievement.

In order to explore this possibility, we regress various measures of teacher quality on the percentage of students in a particular school-grade-year who are eligible for free-lunch. ${ }^{35}$ The results are presented in Table VII. All standard errors are clustered at the school level. Because

\footnotetext{
${ }^{35}$ The results are similar for the percentage of minority students and the average lagged achievement measure.
} 
the principal factors are created by first normalizing the principal survey items to mean zero and standard deviation one within school, it is not useful to compare the principal factors across schools. We therefore focus on "raw" principal responses (measured on a scale of 1-10) for several key survey items. ${ }^{36}$

Columns 1-4 examine the level of various teacher characteristics. The F-statistics on models that include only school fixed effects (shown in the bottom row of the table) confirm that the level of teacher quality varies significantly across schools. However, this variation does not appear to be associated with student poverty. The estimates on percent eligible for free-lunch indicate that there is no significant relationship between school poverty level and teacher valueadded or principal reported measures of teacher quality. ${ }^{37}$ The dependent variable in columns 58 is the range of a particular principal rating within the relevant choice set (i.e., the school*grade*year). The results indicate that the range of principal ratings is smaller in schoolgrade-years with a higher percentage of students who are eligible for free-lunch.

A second concern involves the use of aggregate data. To the extent that minority or lowincome parents never (or very rarely) make a request, observed differences in preferences across schools cannot reflect preference variation related to a child's own free lunch status. To explore this possibility, Table VIII presents information on individual parent requests we were able to obtain from two schools. ${ }^{38}$ The first column shows the average demographic characteristics in the district in 2002-03 to provide a baseline from which to assess the two schools we examine. These two schools are roughly at the $25^{\text {th }}$ and $75^{\text {th }}$ percentiles of the distribution in terms of free

\footnotetext{
${ }^{36}$ Of course, differences in principal ratings across schools may result from differences in how harshly principals rate their teachers.

${ }^{37}$ See Appendix B for more detailed discussion of how the value-added measures are calculated.

${ }^{38}$ For reasons of convenience, these two principals preferred to give us a spreadsheet with individual requests as opposed to the aggregated requests. In terms of request policies and request rates, they are similar to other schools in the district.
} 
lunch eligibility, and thus provide a snapshot which is likely to generalize to the broader sample of schools. Columns 2 and 4 show the demographic composition of the students in these schools; columns 3 and 5 show the composition of students who made requests in these schools. In both schools we see that the students who make requests are more likely to be white and less likely to be eligible for free lunch than the average student in the school. This confirms our earlier findings that free lunch and minority status are associated with increased costs of making a request. However, we also see that a non-trivial percent of requests come from families who are Hispanic, do not speak English as a first language and/or are eligible for free lunch This lends credence to our interpretation that the findings reflect differences in preferences between observably different groups of parents within a school.

Finally, Table IX examines a variety of alternative specifications in order to test the robustness of our results. For the sake of simplicity, we only present estimates for free-lunch eligibility. Other results are available on request. The first row presents the baseline estimates taken from columns 2 and 3 of Table VI. In this baseline specification, the cost of making a request was modeled as a function of grade fixed effects, school fixed effects and the demographic characteristic (i.e., free lunch eligibility). In row 2, we allow the cost function to vary only with grade and the demographic characteristic. The results are substantively the same, though the significance of some coefficients is reduced. In row 3, we allow the cost function to vary by grade*school*year, yielding estimates similar to the baseline. The next set of results examines alternative specifications of the preference parameters. In the baseline model, parent preferences are modeled as function of two key outputs - the teacher's ability to promote student achievement and student satisfaction (both principal-reported). Row 4 includes the principalreported teacher collegiality measure; row 5 includes a several teacher demographics as well as 
the collegiality factor. The results for both specifications are comparable to the baseline. Row 6 presents estimates of a model where the outcome measure includes negative as well as positive request information. More specifically, we apportion each negative request to the other teachers in the school-grade-year in proportion to the number of positive requests these teachers received. Our results remain the same. Row 7 shows the results of a model that uses alternative principal measures. Recall that the student achievement and satisfaction factors used in the baseline analysis were created from a factor analysis that included all of the individual principal items except the principal report of parent satisfaction. We excluded this item because of concerns that it is highly influenced by parent requests, which introduces a simultaneity problem into the model and may bias our estimates. As a further guard against this simultaneity problem, we regress the original factors on the principal satisfaction item on use the residual from the regression as an alternative principal measure of a teacher's ability to raise student achievement and promote student satisfaction. These residual factors are, by construction, orthogonal to a principal's evaluation of a teacher's ability to promote parent satisfaction. As we see from the estimates in row 7, the estimates using these alternative measures yield very similar results, though there is a decrease in the precision of the estimates. Finally, in row 8 we assume that the expected teacher quality associated with making no request is a weighted average of teacher quality where the weights correspond to the number of vacancies in each class. This is consistent with a model in which parents are fully rational and have perfect information. Again, the results are virtually identical to the baseline. 


\section{Conclusions}

In this paper, we examine the parents' revealed preferences for their child's schooling. We find that on average parents strongly prefer teachers that principals describe as the most popular with students, and place relatively less value on a teacher's ability to raise standardized math or reading achievement. These aggregate effects, however, mask striking differences across family demographics. Low-income and minority families strongly value student achievement and are essentially indifferent to the principal's report of a teacher's ability to promote student satisfaction. The results are reversed for higher-income and non-minority families.

Our findings suggest that what parents want from school is likely to depend on family circumstances as well as parent preferences. Thus, we might expect advantaged and disadvantaged parents to exhibit systematic differences with regards particular educational policies or programs even if both sets of parents have the same underlying utility functions. This has important implications for current school reform strategies. For example, it suggests that communities are likely to react quite differently to accountability policies, such as those embodied in No Child Left Behind. It also suggests that school choice could lead to segregation across demographic groups driven by the preferences of the parents. At the same time, however, our findings imply that low-income families are not only able to recognize high quality teachers, but also strongly value student achievement. This result belies the concern that school choice programs will not benefit poor children because their parents will not fully recognize or sufficiently value academic achievement. Finally, our analysis suggests the results of prior school choice studies may be considerably more difficult to interpret than previously realized. In 
particular, the preference for attending racial or socially homogeneous schools that has been documented in prior literature may not reflect a desire for segregation per se, but instead may reflect an interest in a particular type of curriculum or pedagogy with the socioeconomic composition of the school merely serving as a signal of certain practices. 


\section{References}

Aaronson, Daniel, Lisa Barrow and William Sander (2002). “Teachers and student achievement in the Chicago public high schools.” Working Paper Series WP-02-28, Federal Reserve Bank of Chicago

Bayer, Patrick, Fernando Ferreira, and Robert McMillan, “A Unified Framework for Measuring Preferences for Schools and Neighborhoods.” Working paper.

Berry, Steven, Levinsohn, James and Pakes, Ariel (1995). “Automobile Prices in Market Equilibrium.” Econometrica 63(4): 841-890.

Black, Sandra E., “Do Better Schools Matter? Parental Valuation of Elementary Education,” The Quarterly Journal of Economics (May 1999).

Coldren, J. and Boulton, P. (1991). "Happiness as a criterion of parents' choice of school.” Journal of Education Policy 6(2): 169-178.

Figlio, David N. and Maurice E. Lucas (2004). "What's in a Grade? School Report Cards and the Housing Market.” American Economic Review. 94(3): 951-604.

Glazerman, Steven (1998). "Determinants and Consequences of Parental School Choice,” Doctoral Dissertation. University of Chicago, Harris School of Public Policy.

Hanushek, Eric A., John Kain, Daniel M. O’Brien and Steven G. Rivkin (2005). “The Market for Teacher Quality.” NBER Working Paper \#11154.

Jacob, Brian A. (2005). “Accountability, incentives and behavior: the impact of high-stakes testing in the Chicago public schools. Journal of Public Economics.

Jacob, Brian A. and Lars Lefgren (2005). "What Do Parents Value in Education? An Empirical Investigation of Parents’ Revealed Preferences for Teachers.” Working paper.

Jacob, Brian A. and Stephen D. Levitt (2003). “Rotten apples: an investigation of the prevalence and predictors of teacher cheating.” Quarterly Journal of Economics CXVIII(3): 843-878

Henig, Jeffrey R. (1990). "Choice in Public Schools: An Analysis of Transfer Requests in Magnet Schools.” Social Science Quarterly. 71(1): 69-82.

Hoxby, Caroline, “The Effects of School Choice on Curriculum and Atmosphere,” in Paul E. Peterson and Susan Mayer (eds.), Earning and Learning: When Schools Matter, Washington, DC: Brookings Institution Press (1999), pp. 281-316.

Kane, Thomas J. and Douglas O. Staiger (2001). Volatility in School Test Scores: Implications for Test-Based Accountability Systems. UCLA Graduate School of Public Policy Studies, Working paper. 
Lankford, Hamilton and James Wyckoff, "The Effect of School Choice and Residential Location on the Racial Segregation of Students," unpublished paper, State University of New York-Albany (October 2000), http://www.albany.edu/ wyckoff/segpapr14.PDF

Lee, V.E. , Croninger, R.G. and Smith J.B. (1994). "Parental choice of schools and social stratification in education: The paradox of Detroit.” Educational Evaluation and Policy Analysis 16(4): 434-457.

McFadden, Daniel (1973). “Conditional Logit Analysis of Qualitative Choice Behavior.” In P. Zarembka, ed., Frontiers in Econometrics. New York: Academic Press.

Morris, Carl N. (1983). "Parametric empirical Bayes inference: theory and applications.” Journal of the American Statistical Association 78(381): 47-55.

Rockoff, Jonah E. (2004). "The impact of individual teachers on student achievement: evidence from panel data.” American Economic Review 94(2): 247-252.

Rothstein, Jesse, “Good Principals or Good Peers: Parental Valuation of School Characteristics, Tiebout equilibrium, and the Incentive Effects of Competition Among Jurisdictions,” Working Paper \#3, Princeton University, Education Research Section (2003).

Schneider, Mark, and Jack Buckley, "What Do Parents Want From Schools? Evidence from the Internet,” Educational Evaluation and Policy Analysis, 24 n. 2 (2002), 133-144.

Sims (2005). “How Flexible is Education Production? Combination Classes vs. Class Size.” Working Paper, Brigham Young University.

Sullivan, Daniel G. (2001). "A note on the estimation of regression models with heteroskedastic measurement errors.” Working paper 2001-23. Federal Reserve Bank of Chicago.

Weiher, Gregory R. and Kent L. Tedin (2002). "Does Choice Lead to Racially Distinctive Schools? Charter Schools and Household Preferences.” Journal of Policy Analysis and Management, 21(1): 79-92. 


\section{Appendix A: Sample Principal Survey Form}

We thank you for agreeing to answer the questions in this survey. By answering this survey, you will aid in determining what aspects of teacher effectiveness are most important for students, parents, and principals. Your responses to these surveys will be completely confidential. They will never be revealed to any teachers, administrators, parents, or students. Only statistical averages and correlations will be presented in reports for the district and possible publication in an academic journal.

We will now ask you to rate teachers on the basis of a number of different performance criteria. Please use the following descriptions in rating teachers on a scale of 1 to 10 .

1-2: $\quad$ Inadequate - The teacher performs substantially below minimal standards in this area.

3-5: $\quad$ Adequate - The teacher meets minimal standards (but could make substantial improvements in this area).

6-8: $\quad$ Very good - The teacher is highly effective in this area.

9-10: Exceptional - The teacher is among the best I have ever seen in this area (e.g., in the top 1\% of teachers).

\begin{tabular}{|c|c|c|c|c|c|}
\hline Teacher Characteristic & Teacher 1 & Teacher 2 & Teacher 3 & Teacher 4 & Teacher 5 \\
\hline Dedication and work ethic & & & & & \\
\hline Organization & & & & & \\
\hline Classroom management & & & & & \\
\hline Raising student math achievement & & & & & \\
\hline Raising student reading achievement & & & & & \\
\hline Role model for students & & & & & \\
\hline Student satisfaction with teacher & & & & & \\
\hline Parent satisfaction with teacher & & & & & \\
\hline Positive relationship with colleagues & & & & & \\
\hline Positive relationship with administrators & & & & & \\
\hline Overall teacher effectiveness & & & & & \\
\hline $\begin{array}{l}\text { How many years have you worked with this teacher (in your } \\
\text { current school or another school)? }\end{array}$ & & & & & \\
\hline $\begin{array}{l}\text { How many years has this individual been teaching (in your school } \\
\text { or another)? Please give your best guess if you are not certain. }\end{array}$ & & & & & \\
\hline
\end{tabular}


TABLE A-1

CORRELATION MATRIX OF PRINCIPAL RATING ITEMS

\begin{tabular}{|c|c|c|c|c|c|c|c|c|c|c|c|}
\hline & $\begin{array}{c}\text { Dedicati } \\
\text { on and } \\
\text { Work } \\
\text { Ethic }\end{array}$ & $\begin{array}{l}\text { Organiza } \\
\text { tion }\end{array}$ & $\begin{array}{c}\text { Classroo } \\
\text { m } \\
\text { Manage } \\
\text { ment }\end{array}$ & Math & Reading & $\begin{array}{l}\text { Role } \\
\text { Model }\end{array}$ & $\begin{array}{c}\text { Stud. } \\
\text { Satisfacti } \\
\text { on }\end{array}$ & $\begin{array}{c}\text { Parent } \\
\text { Satisfacti } \\
\text { on }\end{array}$ & $\begin{array}{c}\text { Positive } \\
\text { relations } \\
\text { hip with } \\
\text { colleague } \\
\text { s } \\
\end{array}$ & $\begin{array}{l}\text { Positive } \\
\text { relations } \\
\text { hip with } \\
\text { admin }\end{array}$ & Overall \\
\hline Dedication and work ethic & 1.00 & & & & & & & & & & \\
\hline Organization & 0.595 & 1.00 & & & & & & & & & \\
\hline Classroom management & 0.517 & 0.717 & 1.00 & & & & & & & & \\
\hline $\begin{array}{l}\text { Raising student math } \\
\text { achievement }\end{array}$ & 0.516 & 0.637 & 0.640 & 1.00 & & & & & & & \\
\hline $\begin{array}{l}\text { Raising student reading } \\
\text { achievement }\end{array}$ & 0.569 & 0.641 & 0.643 & 0.629 & 1.00 & & & & & & \\
\hline Role model for students & 0.454 & 0.533 & 0.511 & 0.475 & 0.502 & 1.00 & & & & & \\
\hline $\begin{array}{l}\text { Student satisfaction with } \\
\text { teacher }\end{array}$ & 0.336 & 0.467 & 0.525 & 0.415 & 0.427 & 0.757 & 1.00 & & & & \\
\hline $\begin{array}{l}\text { Parent satisfaction with } \\
\text { teacher }\end{array}$ & 0.376 & 0.497 & 0.581 & 0.453 & 0.503 & 0.689 & 0.785 & 1.00 & & & \\
\hline $\begin{array}{l}\text { Positive relationship with } \\
\text { colleagues }\end{array}$ & 0.335 & 0.392 & 0.342 & 0.350 & 0.384 & 0.624 & 0.574 & 0.544 & 1.00 & & \\
\hline $\begin{array}{l}\text { Positive relationship with } \\
\text { administrators }\end{array}$ & 0.586 & 0.707 & 0.727 & 0.696 & 0.708 & 0.733 & 0.685 & 0.538 & 0.759 & 1.00 & \\
\hline $\begin{array}{l}\text { Overall teacher } \\
\text { effectiveness }\end{array}$ & 0.586 & 0.707 & 0.727 & 0.696 & 0.708 & 0.733 & 0.685 & 0.691 & 0.656 & 0.675 & 1.00 \\
\hline
\end{tabular}

Notes: All measures are normalized within school to mean zero and standard deviation one. 


\section{Appendix B: The Construction of Teacher Value-Added Measures}

This appendix describes several important identification and estimation issues in greater detail. The greatest challenge in estimating measures of teacher value-added is to account for non-random assignment of students and teachers. With the assistance of district administrators, we conducted detailed interviews with principals to ascertain exactly how students are assigned to classrooms and to explicitly examine how the assignment process may influence our estimates. In many schools, particularly in sixth grade, it turns out that students are tracked for math instruction. In these cases, we do not construct value-added measures for math achievement, and a teacher's value-added is therefore based solely on his or her performance in raising reading scores.

To account for unobservable, time-invariant student characteristics, we estimate models that include student fixed effects $\lambda_{i}$ with either achievement levels or gains as the dependent variable:

$$
\begin{aligned}
& y_{i j k t}=C_{j t} \mathrm{~B}+X_{i t} \Gamma+\psi_{t}+\phi_{k}+\delta_{j}+\alpha_{j t}+\lambda_{i}+\varepsilon_{i j k t} \\
& y_{i j k t}-y_{i j k t-1}=C_{j t} \mathrm{~B}+X_{i t} \Gamma+\psi_{t}+\phi_{k}+\delta_{j}+\alpha_{j t}+\lambda_{i}+\varepsilon_{i j k t}
\end{aligned}
$$

We find that teacher effects that include virtually no controls are highly correlated with valueadded measures that include a much more detailed set of controls, suggesting that students are not systematically sorting into classrooms along observable dimensions and thus providing some assurance that they may not be sorting along unobservable dimensions either.

Finally, in order to directly examine how parental requests might influence our estimates of teacher value-added, we examine the relationship between parent request and student performance for a subset of our sample for which we have access to individual request data. Conditional on initial achievement and basic demographics, we find that the students whose 
parents submit requests do not perform significantly better or worse than non-requesting students. This suggests that teacher assignment on the basis of parent requests is unlikely to be highly correlated with unobserved student ability.

While the estimation of the teacher effects described in the text is relatively straightforward, one point is worth noting. The identification of teacher quality in a typical value-added model is based on a teacher's performance relative to other teachers in the district (even if school fixed effects are included), owing to teacher mobility across schools and the presence of covariates that likely vary considerably across classrooms. In our analysis, we believe it is more reasonable to measure teacher quality relative to a school norm, since this is most likely the relevant comparison group that parents will consider. To insure we identify estimates of teacher quality relative to other teachers within the same school, we examine teachers who are in their most recent school (i.e. for the small number of switching teachers, we drop any observations from their first school), include school fixed effects and then constrain the teacher fixed effects to sum to zero within each school.

For the table in which we examine how the average quality of teachers varies across schools, we estimate teacher value-added with a specification that includes student fixed effects but not school fixed effects. The student fixed effects ensure that our results are not biased by unobserved heterogeneity across schools. We also include teachers in all schools at which they taught. The movement of teachers and students across schools identifies teacher quality estimates that can be compared across schools. With such specifications, however, the estimation error of teacher value added is often highly correlated across teachers. This makes it difficult to appropriately correct for the attenuation bias resulting from the use of value-added measures that are estimated. 
To show that our primary results are robust to our construction of teacher value-added, we show estimation results that rely on alternative value-added measures. In rows 2 and 3, we control for teacher experience to take into account that teacher quality may be changing over time. The results are unchanged. In row 4, we calculate value-added using achievement gains that take into account that the average gain differs based on a student's lagged test score. This yields results that are again similar to the baseline. In rows 5 and 6 we rely on value-added specifications with student fixed effects, which fails to change the estimates. Finally, in rows 710, we calculate value-added based on only reading or math achievement. The results are again virtually identical with the exception of when we calculate value-added using normalized reading gains and student fixed effects. Even in this specification, however, the standard errors are too large to rule out an effect similar to the baseline estimate. Overall, it appears that our findings are robust to our construction of value-added measures. 
TABLE B-1

SENSITIVITY ANALYSES FOR VALUE-ADDED SPECIFICATIONS

\begin{tabular}{|c|c|c|c|c|c|}
\hline & & \multicolumn{2}{|c|}{$\begin{array}{c}\text { Student Satisfaction Factor } \\
\text { Structural Coefficient } \\
\text { [Marginal Effect] } \\
\end{array}$} & \multicolumn{2}{|c|}{$\begin{array}{c}\text { Value-added Measure } \\
\text { Structural Coefficient } \\
\text { [Marginal Effect] } \\
\end{array}$} \\
\hline & & $\begin{array}{l}\text { Eligible for } \\
\text { Free Lunch }\end{array}$ & $\begin{array}{l}\text { Not eligible for } \\
\text { free lunch }\end{array}$ & $\begin{array}{l}\text { Eligible for } \\
\text { Free Lunch }\end{array}$ & $\begin{array}{l}\text { Not eligible for } \\
\text { free lunch }\end{array}$ \\
\hline 1 & $\begin{array}{l}\text { Baseline } \\
\text { Dependent variable is a composite math-reading score. Includes } \\
\text { school, grade and year fixed effects, prior achievement and other } \\
\text { covariates, but no student fixed effects. }\end{array}$ & $\begin{array}{c}0.436 \dagger \\
{[0.030]}\end{array}$ & $\begin{array}{l}0.706^{*} \\
{[0.059]}\end{array}$ & $\begin{array}{l}2.999 \dagger \\
{[0.208]}\end{array}$ & $\begin{array}{c}-1.864 \\
{[-0.156]}\end{array}$ \\
\hline 2 & Baseline + indicator for first-year teachers & $\begin{array}{l}0.446^{*} \\
{[0.032]}\end{array}$ & $\begin{array}{l}0.691^{*} \\
{[0.058]}\end{array}$ & $\begin{array}{l}3.312^{*} \\
{[0.227]}\end{array}$ & $\begin{array}{c}-2.077 \\
{[-0.175]}\end{array}$ \\
\hline 3 & Baseline $+\ln ($ experience) variable & $\begin{array}{l}0.437^{*} \\
{[0.030]}\end{array}$ & $\begin{array}{l}0.702^{*} \\
{[0.059]}\end{array}$ & $\begin{array}{l}2.981^{*} \\
{[0.205]}\end{array}$ & $\begin{array}{c}-1.869 \\
{[-0.157]}\end{array}$ \\
\hline 4 & $\begin{array}{l}\text { Dependent variable is achievement gain score based on math-reading } \\
\text { composite normalized by prior achievement. Does not include student } \\
\text { fixed effects. }\end{array}$ & $\begin{array}{l}0.423^{*} \\
{[0.029]}\end{array}$ & $\begin{array}{l}0.738^{*} \\
{[0.062]}\end{array}$ & $\begin{array}{l}2.184^{*} \\
{[0.150]}\end{array}$ & $\begin{array}{l}-1.654^{*} \\
{[-0.139]}\end{array}$ \\
\hline 5 & $\begin{array}{l}\text { Baseline + student fixed effects (but excluding lagged test score and } \\
\text { student covariates) }\end{array}$ & $\begin{array}{l}0.406 \dagger \\
{[0.028]}\end{array}$ & $\begin{array}{l}0.737^{*} \\
{[0.062]}\end{array}$ & $\begin{array}{c}2.714 \\
{[0.188]}\end{array}$ & $\begin{array}{c}-1.049 \\
{[-0.089]}\end{array}$ \\
\hline 6 & Row 4 Model + student fixed effects & $\begin{array}{c}0.385 \\
{[0.026]}\end{array}$ & $\begin{array}{l}0.766^{*} \\
{[0.065]}\end{array}$ & $\begin{array}{c}1.648 \\
{[0.113]}\end{array}$ & $\begin{array}{c}-0.794 \\
{[-0.067]}\end{array}$ \\
\hline 7 & $\begin{array}{l}\text { Baseline Model using reading score instead of math-reading } \\
\text { composite }\end{array}$ & $\begin{array}{l}0.387 \dagger \\
{[0.027]}\end{array}$ & $\begin{array}{l}0.732^{*} \\
{[0.061]}\end{array}$ & $\begin{array}{l}2.736 \\
{[0.195]}\end{array}$ & $\begin{array}{l}-1.485 \\
{[-0.123]}\end{array}$ \\
\hline 8 & Row 6 Model using reading score instead of math-reading composite & $\begin{array}{c}0.452 \\
{[0.032]}\end{array}$ & $\begin{array}{l}0.708^{*} \\
{[0.060]}\end{array}$ & $\begin{array}{l}0.090 \\
(1.481) \\
{[0.007]}\end{array}$ & $\begin{array}{c}0.173 \\
(1.305) \\
{[0.015]}\end{array}$ \\
\hline 9 & Baseline Model using math score instead of math-reading composite & $\begin{array}{l}0.522^{*} \\
{[0.035]}\end{array}$ & $\begin{array}{l}0.689^{*} \\
{[0.058]}\end{array}$ & $\begin{array}{l}2.415^{*} \\
{[0.161]}\end{array}$ & $\begin{array}{l}-1.804^{*} \\
{[-0.153]}\end{array}$ \\
\hline 10 & Row 6 Model using math score instead of math-reading composite & $\begin{array}{l}0.472 \dagger \\
{[0.031]}\end{array}$ & $\begin{array}{l}0.711^{*} \\
{[0.060]}\end{array}$ & $\begin{array}{l}2.995^{*} \\
{[0.194]}\end{array}$ & $\begin{array}{l}-1.256^{*} \\
{[-0.106]} \\
\end{array}$ \\
\hline
\end{tabular}

Notes: Sample includes only grades 2-6 $(\mathrm{n}=331)$. Demographics are measured at the school-grade-year level. $*=$ significant at 5 percent level. $\dagger=$ significant at 10 percent level. 


\section{Appendix C: Statistical Properties of Empirical Bayes (EB) Estimates of Teacher Quality}

The intuition behind the EB approach is that one can construct more efficient estimates of teacher quality by "shrinking” noisy estimates of teacher effectiveness to the mean of the teacher quality distribution. Because each realization of a teacher's value-added reflects both actual ability as well as measurement error, noisy estimates provide less information regarding true teacher quality than more precise estimates. The EB estimate for teacher $j$ is essentially a weighted average of the teacher's fixed effect and the average value-added within the population, where the weight is a function of the reliability of each teacher's fixed effect. This approach is conceptually quite similar to the approach outlined by Sullivan (2001), which involves extending a traditional errors-in-variables correction to allow for heteroskedastic measurement error.

Suppose we have a noisy measure of teacher quality $\hat{\delta}_{j}=\delta_{j}+e_{j}$, where $\delta_{j}$ is actual teacher ability, $\hat{\delta}_{j}$ is unbiased OLS estimate of teacher ability, and $e_{j}$ is a mean zero error term. Further assume that both $\delta_{j}$ and $e_{j}$ are normally distributed with a known mean and variance. If one knew the mean and variance of the distributions of $\delta_{j}$ and $e_{j}$, one could construct a more efficient estimate of $\delta_{j}$ that optimally incorporates available intuition. Indeed, it is straightforward to show that $E\left[\delta_{j} \mid \hat{\delta}_{j}\right]=\left(1-\lambda_{j}\right) \bar{\delta}+\left(\lambda_{j}\right) \hat{\delta}_{j}$ where $\lambda_{j}=\frac{\sigma_{\delta}^{2}}{\sigma_{\delta}^{2}+\sigma_{e_{j}}^{2}}$. The EB estimate for teacher $\mathrm{j}$ is exactly this expected value: $E\left[\delta_{j} \mid \hat{\delta}_{j}\right]=\hat{\delta}_{j}^{E B}$. In practice, the mean of the teacher ability distribution, $\bar{\delta}$, is unidentified so all of the effects are centered around zero. Note that we assume that teacher quality is distributed normally with variance $\sigma_{\delta}^{2}$ while $\sigma_{e_{j}}^{2}$ is the variance of the measurement error for teacher $j$ 's fixed effect, which can vary across observations depending on the amount of data used to construct the estimate. 
Of course, the mean of the teacher quality distribution and the variance of the error term are not generally known and must be estimated. One can construct an empirical analog to the expectation above using the method proposed by Morris (1983). This essentially involves using the estimated mean and variance to calculate the appropriate shrinkage factor, $\lambda_{j}$, and incorporating an appropriate degrees of freedom adjustment. ${ }^{39}$ We will refer to this estimate as $\hat{\delta}_{j}^{E B}$. The resulting properties of this EB estimate are essentially the same as if these parameters were known, so for simplicity we will act as if the parameters were known for the remainder of the discussion.

One can easily show that using the EB estimates as an explanatory variable in a regression context will yield point estimates that are unaffected by the attenuation bias that would exist if one used simple OLS estimates. Define the error of the EB estimate as $v_{j}$, so that $\delta_{j}=\hat{\delta}_{j}^{E B}+v_{j}$. Because the EB procedure takes advantage of all available information to construct the estimated teacher effect — indeed it is the empirical analog to the conditional expectation of $\delta_{j}$ - the shrinkage estimator is uncorrelated with the error term: $\operatorname{cov}\left(v, \hat{\delta}^{E B}\right)=0$. In fact, the shrinkage estimate can also be thought of as the predicted value from a regression of the actual teacher quality on the noisy measure. By construction, this prediction is orthogonal to the residual $v_{j}$.

Too see that the EB estimate of teacher quality will yield unbiased estimates when used as an explanatory variable in a regression context, consider the following simple regression equation:

\footnotetext{
${ }^{39}$ The degrees of freedom adjustment takes into account that the mean that we are shrinking toward is estimatednot known.
} 


$$
\begin{aligned}
y_{j} & =\beta_{0}+\beta_{1} \delta_{j}+u_{j} \\
& =\beta_{0}+\beta_{1} \hat{\delta}_{j}^{E B}+\beta_{1} v_{j}+u_{j}
\end{aligned}
$$

Because, $\hat{\delta}_{j}^{E B}$ is orthogonal to the composite error term, $\beta_{1} v_{j}+u_{j}$, we know the resulting estimate of $\beta_{1}$ will be unbiased.

Now suppose that it is known that the distribution of value added varies across a set of $K$ different groups. For example, the distribution of actual teacher quality may vary by gender or experience. In this case, the conditional expectation of $\delta_{j}$ is $E\left(\delta_{j} \mid \hat{\delta}_{j}\right.$, group $\left.=k\right)=\left(1-\lambda_{j}\right) \bar{\delta}_{k}+\lambda_{j} \hat{\delta}_{j}$, where $\bar{\delta}_{k}$ is the mean of teacher quality of teachers in group $k$. Additionally, $\lambda_{j}$ must be constructed using the variance of $\delta_{j}$ around the groupspecific mean. Morris' (1983) method of constructing EB estimates readily generalizes to this situation, though in practice it may be necessary to impose substantial structure on the conditional mean. ${ }^{40}$ The advantage of allowing the mean of the teacher quality measure to vary with covariates is that one can generate more precise estimates of teacher quality. Furthermore, the error of the EB estimate will be orthogonal to every piece of information (e.g. gender) used to construct it. This guarantees regression coefficient estimates that are unbiased by measurement error in a context that includes covariates besides the EB measure itself.

\footnotetext{
${ }^{40}$ For example, one may need to assume that the conditional mean of teacher ability is a quadratic function of experience to conserve degrees of freedom.
} 


\section{Appendix D: OLS Estimates of Parent Requests}

Tables VI and VII explore the heterogeneity in parent preferences across family demographics. Since we do not have student-level request information, we calculate the average demographic characteristics of all students in each school-grade-year (e.g., the fraction of students who are eligible for free lunch). We then categorize school-grade-year observations on the basis of these aggregate demographic measures. To focus on educational outputs, we regress our normalized parent request variable on the principal's assessment of a teacher's ability to promote student satisfaction and to promote student achievement (including fixed effects for school-grade-year, but no other covariates). Table D1 shows the OLS estimates for several different subgroups. Column 2, for example, presents estimates for school-grade-year observations in which fewer than 50 percent of students were eligible for free lunch. In this group, a teacher's student satisfaction rating is strongly related to the number of requests that he or she receives. The coefficient on a teacher's achievement rating is substantially smaller and not significantly different than zero. In contrast, in classes where at least 50 percent of students were eligible for free lunch, a teacher’s student satisfaction rating has no effect on his or her requests, but a teacher's achievement rating has a strong, positive effect on parent requests. A similar but even stronger pattern is apparent if one compares school-grade-year observations where fewer than (or at least) 20 percent of students are minority. The estimates in columns 6-7 that show the results by prior student achievement level suggest that this finding may be partially related to student achievement. ${ }^{41}$ Table VI presents estimates from a specification that, as

\footnotetext{
${ }^{41}$ We use test scores from the prior year to determine the percent of students scoring in the top half of the district distribution in a school-grade-year. Because we do not have student test scores for the 2003-04 school year, we use test scores for the 2002-03 school year to calculate the prior ability of the cohorts entering in 2004-05.

Unfortunately, we do not have first grade test scores for 2002-03. For this reason, we must exclude second grade classes in both 2003-04 and 2004-05 and third grade classes in 2004-05 from the analyses shown in columns 5-6 in Tables V-A and V-B as well as columns 8-10 in Tables VII-A and VII-B. This is one reason that the reduced precision of these results.
} 
above, includes the student satisfaction measure, but replaces the principal-reported teacher achievement measure with the teacher value-added measure. The results are qualitatively the same. 
TABLE D-1

OLS ESTIMATES OF HETEROGENEITY IN PARENTAL PREFERENCES BY FAMILY DEMOGRAPHICS

\begin{tabular}{|c|c|c|c|c|c|c|c|}
\hline Independent Variable & Full Sample & $\begin{array}{l}\text { Less than } 50 \% \\
\text { of students } \\
\text { eligible for } \\
\text { free or } \\
\text { reduced price } \\
\text { lunch }\end{array}$ & $\begin{array}{l}\text { At least } 50 \% \\
\text { of students } \\
\text { eligible for } \\
\text { free or } \\
\text { reduced price } \\
\text { lunch }\end{array}$ & $\begin{array}{l}\text { Less than } 20 \% \\
\text { of students are } \\
\text { minority }\end{array}$ & $\begin{array}{l}\text { At least } 20 \% \\
\text { of students are } \\
\text { minority }\end{array}$ & $\begin{array}{l}\text { Less than } 50 \% \\
\text { of students } \\
\text { with above } \\
\text { average } \\
\text { achievement } \\
\text { scores }\end{array}$ & $\begin{array}{l}\text { At least } 50 \% \\
\text { of students } \\
\text { with above } \\
\text { average } \\
\text { achievement } \\
\text { scores }\end{array}$ \\
\hline & $(1)$ & $(2)$ & (3) & $(4)$ & (5) & (6) & $(7)$ \\
\hline $\begin{array}{l}\text { Principal's evaluation of the teacher's } \\
\text { ability to promote student satisfaction } \\
\text { (composite measure from factor } \\
\text { analysis) }\end{array}$ & $\begin{array}{l}0.045^{*} \\
(0.009)\end{array}$ & $\begin{array}{l}0.057^{*} \\
(0.012)\end{array}$ & $\begin{array}{c}0.012 \\
(0.009)\end{array}$ & $\begin{array}{l}0.075^{*} \\
(0.013)\end{array}$ & $\begin{array}{l}0.017^{*} \\
(0.007)\end{array}$ & $\begin{array}{c}0.020 \dagger \\
(0.012)\end{array}$ & $\begin{array}{l}0.055^{*} \\
(0.015)\end{array}$ \\
\hline $\begin{array}{l}\text { Principal's evaluation of the teacher's } \\
\text { ability to raise student achievement } \\
\text { (composite measure from factor } \\
\text { analysis) }\end{array}$ & $\begin{array}{l}0.022^{*} \\
(0.011)\end{array}$ & $\begin{array}{c}0.019 \\
(0.015)\end{array}$ & $\begin{array}{l}0.026^{*} \\
(0.010)\end{array}$ & $\begin{array}{c}0.019 \\
(0.016)\end{array}$ & $\begin{array}{l}0.034^{*} \\
(0.010)\end{array}$ & $\begin{array}{l}0.046^{*} \\
(0.015)\end{array}$ & $\begin{array}{c}0.022 \\
(0.017)\end{array}$ \\
\hline Number of observations & 251 & 150 & 101 & 113 & 138 & 56 & 122 \\
\hline $\begin{array}{l}\text { Fraction of parents requesting any } \\
\text { teacher }\end{array}$ & 0.284 & 0.352 & 0.190 & 0.376 & 0.207 & 0.213 & 0.326 \\
\hline $\begin{array}{l}\text { Average fraction of parents requesting } \\
\text { the an individual teacher }\end{array}$ & 0.092 & 0.114 & 0.061 & 0.126 & 0.063 & 0.070 & 0.111 \\
\hline
\end{tabular}


TABLE D-2

OLS ESTIMATES OF HETEROGENEITY IN PARENTAL PREFERENCES BY FAMILY DEMOGRAPHICS

\begin{tabular}{|c|c|c|c|c|c|c|c|}
\hline Independent Variable & Full Sample & $\begin{array}{l}\text { Less than } 50 \% \\
\text { of students } \\
\text { eligible for } \\
\text { free or } \\
\text { reduced price } \\
\text { lunch }\end{array}$ & $\begin{array}{l}\text { At least } 50 \% \\
\text { of students } \\
\text { eligible for } \\
\text { free or } \\
\text { reduced price } \\
\text { lunch }\end{array}$ & $\begin{array}{l}\text { Less than } 20 \% \\
\text { of students are } \\
\text { minority }\end{array}$ & $\begin{array}{l}\text { At least } 20 \% \\
\text { of students are } \\
\text { minority }\end{array}$ & $\begin{array}{l}\text { Less than } 50 \% \\
\text { of students } \\
\text { with above } \\
\text { average } \\
\text { achievement } \\
\text { scores }\end{array}$ & $\begin{array}{l}\text { At least } 50 \% \\
\text { of students } \\
\text { with above } \\
\text { average } \\
\text { achievement } \\
\text { scores }\end{array}$ \\
\hline & $(1)$ & $(2)$ & (3) & (4) & (5) & (6) & $(7)$ \\
\hline $\begin{array}{l}\text { Principal's evaluation of the teacher's } \\
\text { ability to promote student satisfaction } \\
\text { (composite measure from factor } \\
\text { analysis) }\end{array}$ & $\begin{array}{l}0.054^{*} \\
(0.007)\end{array}$ & $\begin{array}{l}0.067^{*} \\
(0.009)\end{array}$ & $\begin{array}{l}0.024 * \\
(0.009)\end{array}$ & $\begin{array}{c}0.083^{*} \\
(0.011)\end{array}$ & $\begin{array}{l}0.031^{*} \\
(0.006)\end{array}$ & $\begin{array}{c}0.036^{*} \\
(0.012)\end{array}$ & $\begin{array}{l}0.063^{*} \\
(0.012)\end{array}$ \\
\hline Teacher value-added & $\begin{array}{c}0.025 \\
(0.036)\end{array}$ & $\begin{array}{l}-0.075 \\
(0.047)\end{array}$ & $\begin{array}{l}0.079 * \\
(0.040)\end{array}$ & $\begin{array}{l}-0.042 \\
(0.065)\end{array}$ & $\begin{array}{c}0.061 \\
(0.039)\end{array}$ & $\begin{array}{l}-0.003 \\
(0.068)\end{array}$ & $\begin{array}{l}-0.022 \\
(0.072)\end{array}$ \\
\hline Number of observations & & 150 & 101 & 113 & 138 & 56 & 122 \\
\hline $\begin{array}{l}\text { Fraction of parents requesting any } \\
\text { teacher }\end{array}$ & 0.284 & 0.352 & 0.190 & 0.376 & 0.207 & 0.213 & 0.326 \\
\hline $\begin{array}{l}\text { Average fraction of parents requesting a } \\
\text { particular teacher }\end{array}$ & 0.092 & 0.114 & 0.061 & 0.126 & 0.063 & 0.070 & 0.111 \\
\hline
\end{tabular}




\section{FIGURE I}

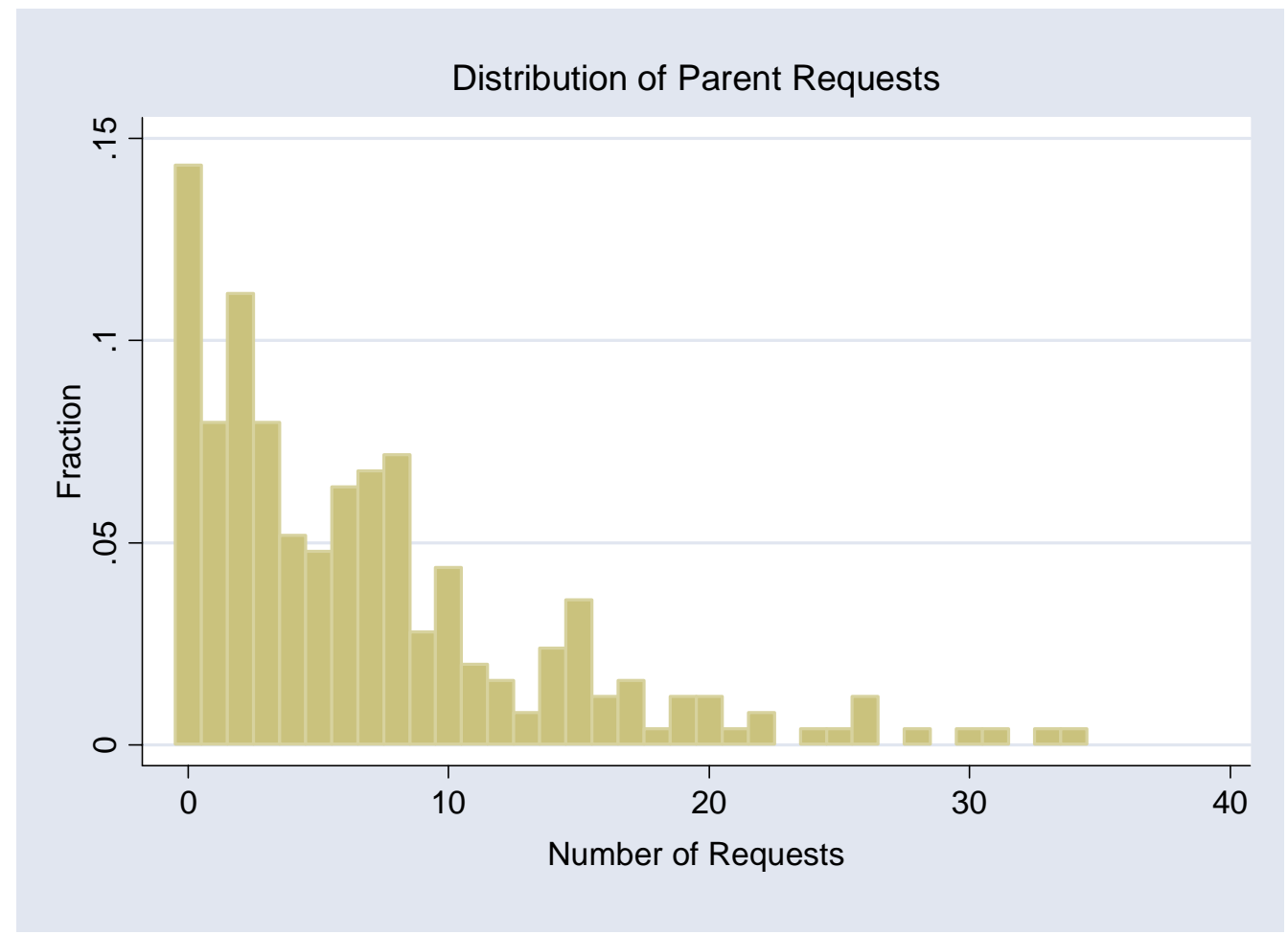

FIGURE II

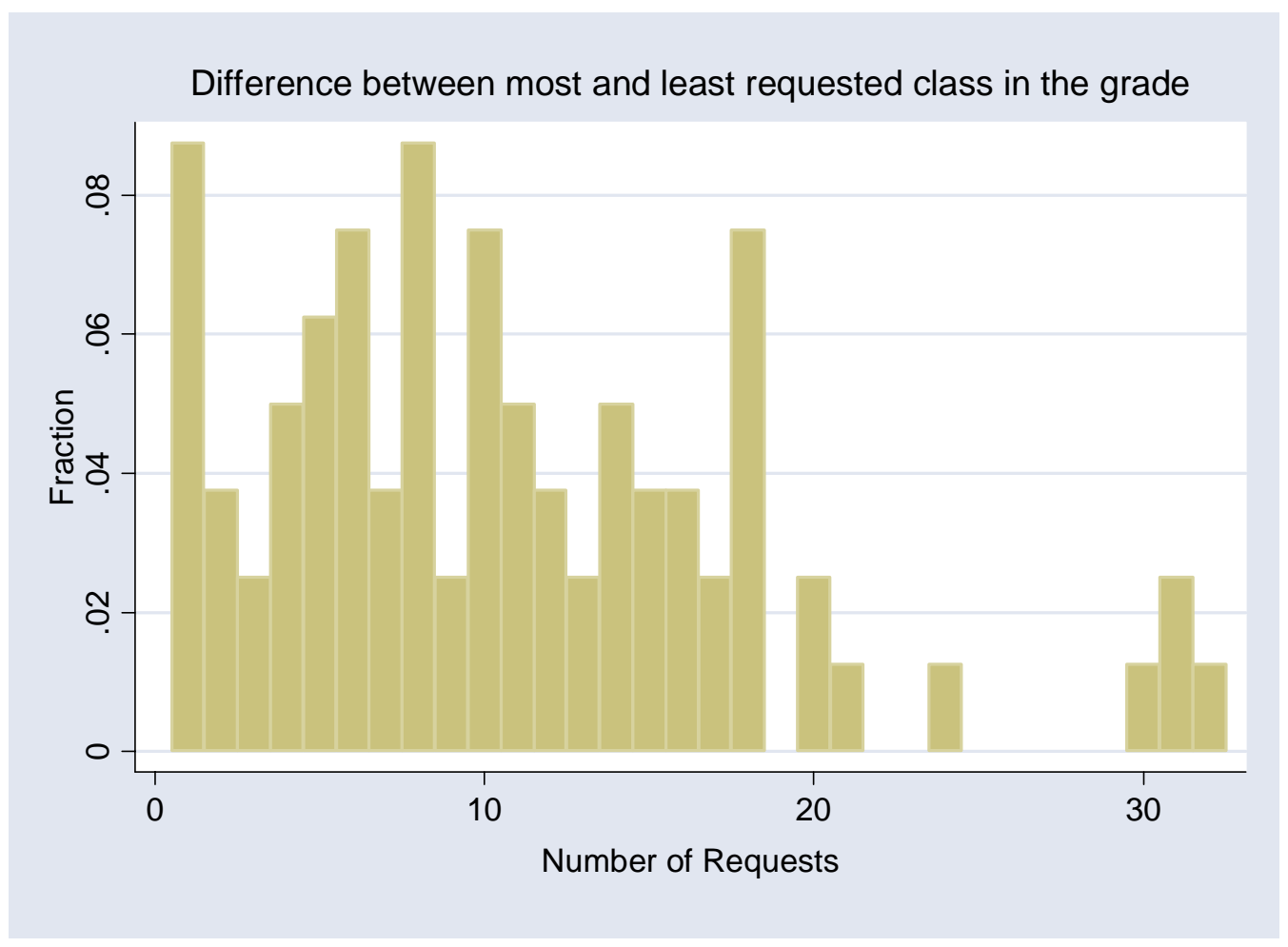




\section{FIGURE III}

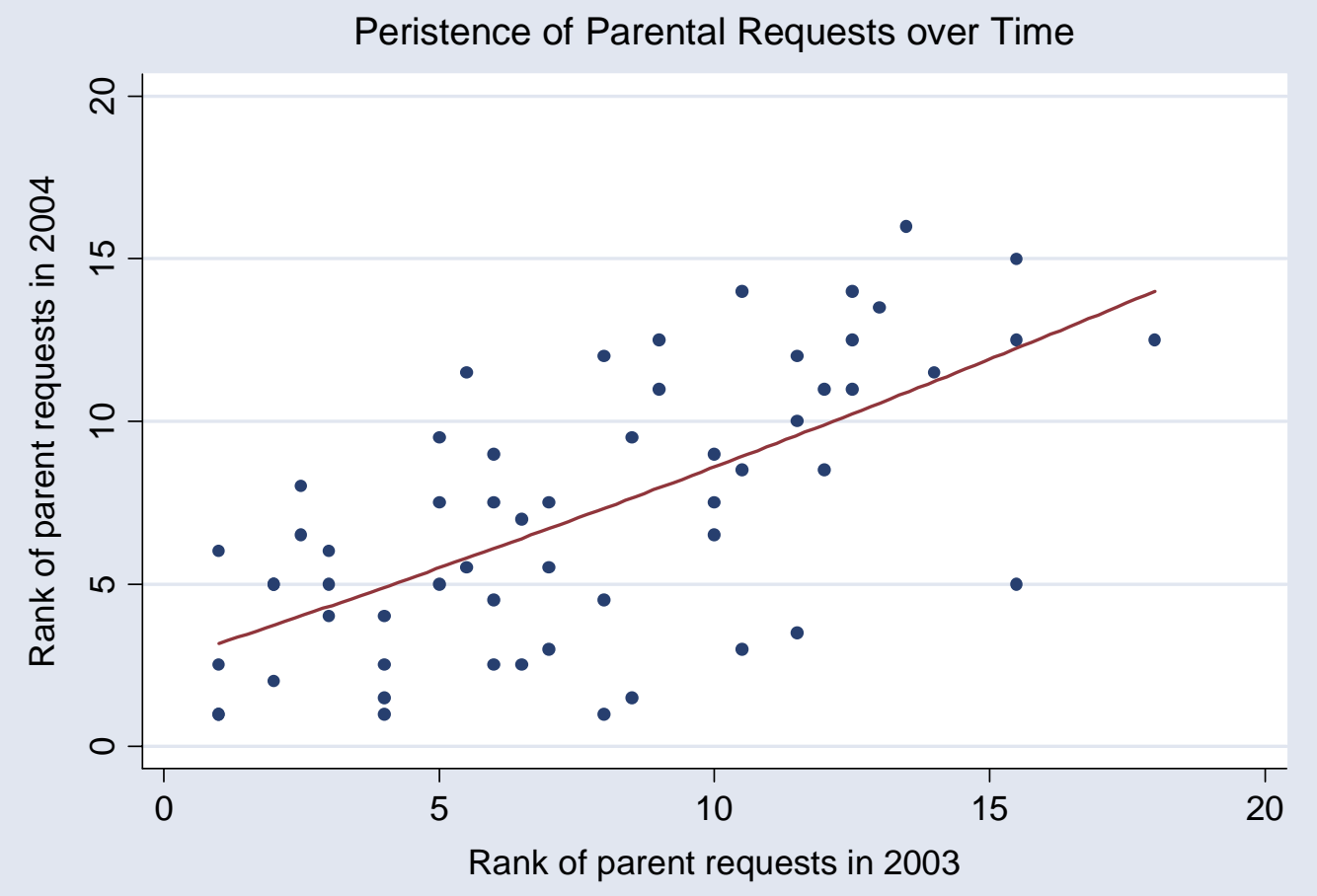


FIGURE IV

DISTRIBUTION OF PRINCIPAL RATINGS WITHIN SCHOOL

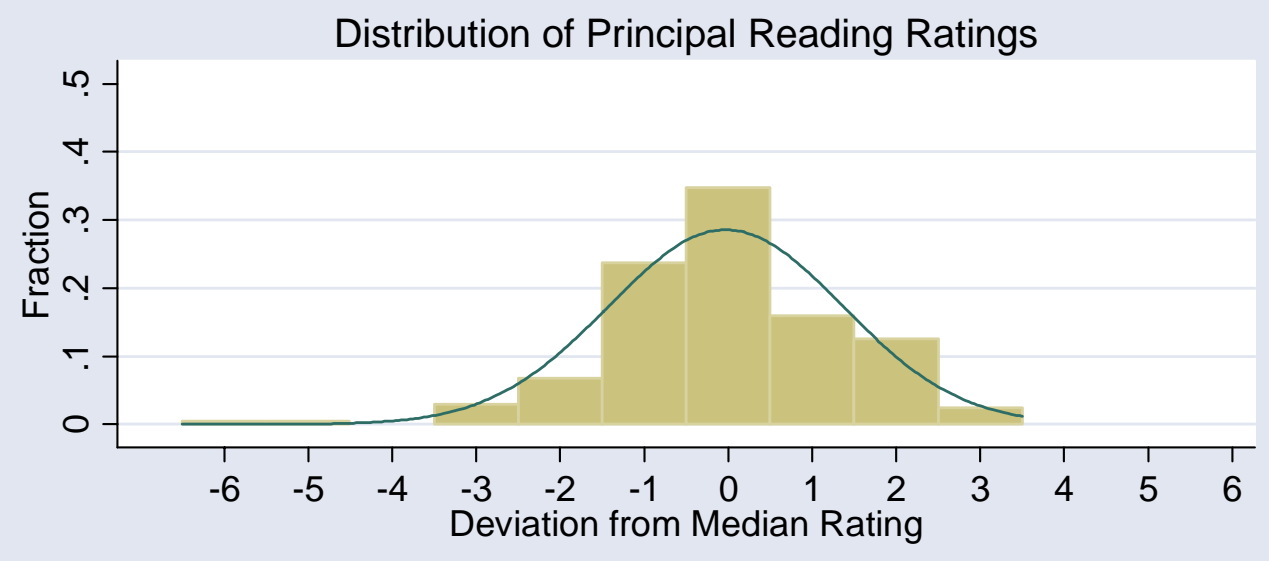

Distribution of Principal Math Ratings

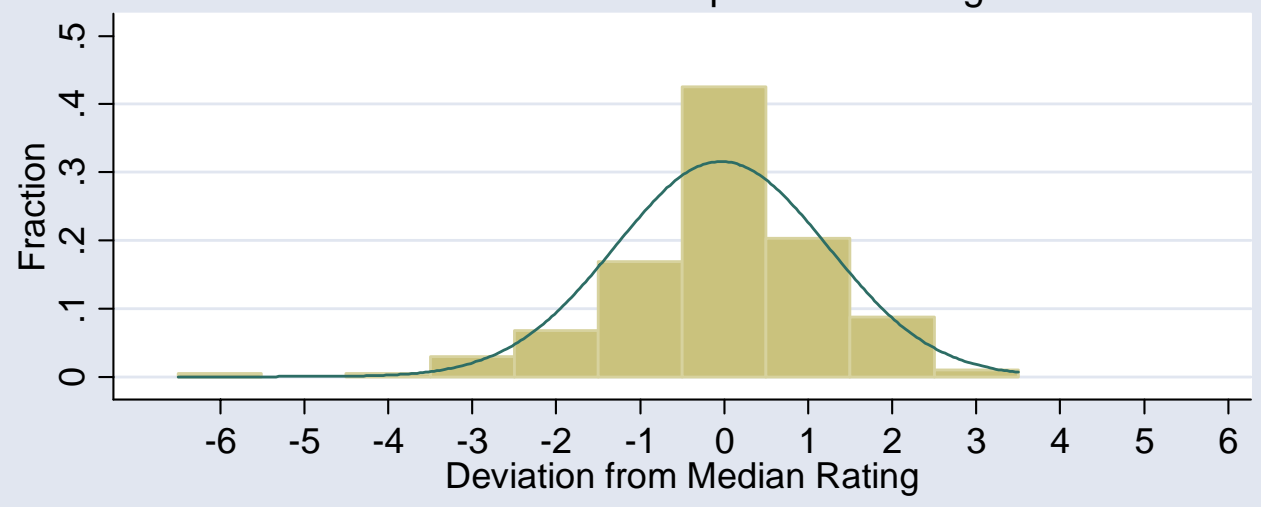

Distribution of Principal Reading Ratings

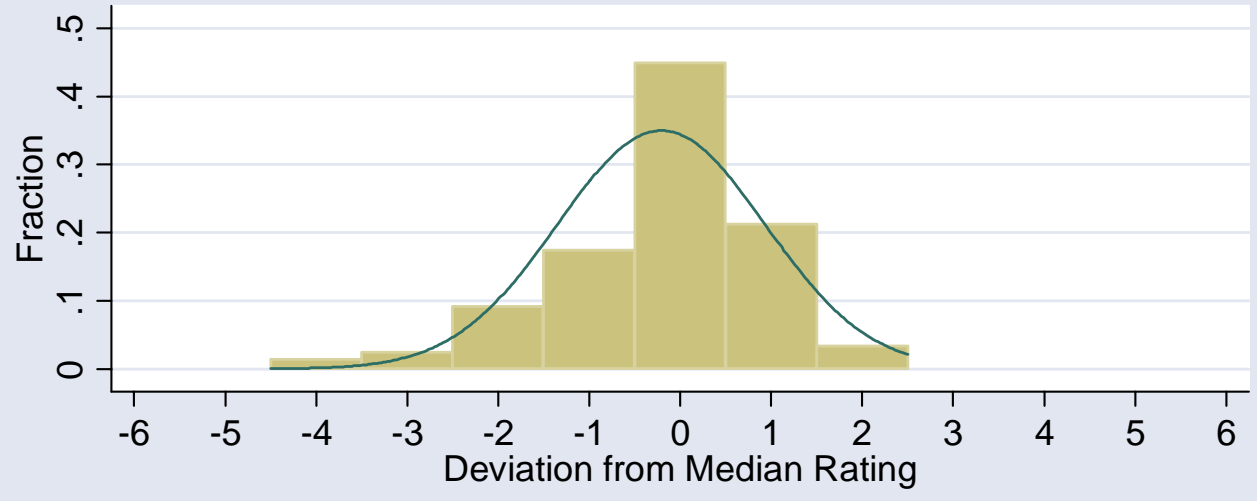


TABLE I

SUMMARY STATISTICS

\begin{tabular}{|c|c|c|c|c|c|}
\hline \multirow[b]{2}{*}{ Teacher Characteristic } & \multicolumn{2}{|c|}{ Overall } & \multicolumn{3}{|c|}{$\begin{array}{l}\text { Range within choice set } \\
\text { (i.e., school-grade-year) }\end{array}$} \\
\hline & Mean & $\begin{array}{l}\text { Standard } \\
\text { deviation }\end{array}$ & $\begin{array}{l}\text { Mean of } \\
\text { range }\end{array}$ & $\begin{array}{l}25^{\text {th }} \\
\text { percentile of } \\
\text { range } \\
\end{array}$ & $\begin{array}{l}75^{\text {th }} \\
\text { percentile of } \\
\text { range }\end{array}$ \\
\hline Male & 0.14 & 0.34 & 0.36 & 0 & 1 \\
\hline Age & 43.69 & 12.58 & 19.24 & 10 & 29 \\
\hline First year teacher & 0.09 & 0.28 & 0.29 & 0 & 1 \\
\hline 2-5 years of experience & 0.16 & 0.36 & 0.47 & 0 & 1 \\
\hline 6-10 years of experience & 0.23 & 0.42 & 0.56 & 0 & 1 \\
\hline $11-20$ years of experience & 0.21 & 0.41 & 0.52 & 0 & 1 \\
\hline 21+ years experience & 0.31 & 0.46 & 0.58 & 0 & 1 \\
\hline $\begin{array}{l}\text { First year in the school (with }>1 \text { year of } \\
\text { experience) }\end{array}$ & 0.07 & 0.26 & 0.28 & 0 & 1 \\
\hline BA Degree at in state (but not local) college & 0.14 & 0.35 & 0.40 & 0 & 1 \\
\hline BA Degree at out of state college & 0.04 & 0.19 & 0.16 & 0 & 0 \\
\hline MA Degree & 0.15 & 0.36 & 0.42 & 0 & 1 \\
\hline Any additional endorsements & 0.22 & 0.41 & 0.48 & 0 & 1 \\
\hline Enrollment in grade-school-year & 79.18 & 15.61 & 0 & 0 & 0 \\
\hline Mixed grade classroom & 0.10 & 0.31 & 0.12 & 0 & 0 \\
\hline Two teachers in the classroom & 0.03 & 0.18 & 0.09 & 0 & 0 \\
\hline Dual language classroom & 0.02 & 0.13 & 0.05 & 0 & 0 \\
\hline Number of positive requests & 6.88 & 6.91 & 10.96 & 6 & 15 \\
\hline Number of negative requests & 0.35 & 1.10 & 0.98 & 0 & 2 \\
\hline $\begin{array}{l}\text { Teacher Value-Added (EB estimate of math- } \\
\text { reading composite) }\end{array}$ & 0.00 & 0.18 & 0.20 & 0.07 & 0.29 \\
\hline Student satisfaction factor & 0.05 & 1.00 & 1.29 & 0.05 & 2.14 \\
\hline Student achievement factor & 0.09 & 0.88 & 1.25 & 0.39 & 2.16 \\
\hline Teacher collegiality factor & 0.06 & 0.91 & 1.27 & 0.38 & 1.85 \\
\hline Overall teacher effectiveness & 8.09 & 1.22 & 1.48 & 0.5 & 2 \\
\hline Dedication and work ethic & 8.50 & 1.50 & 1.75 & 0 & 3 \\
\hline Organization & 7.97 & 1.55 & 1.99 & 1 & 3 \\
\hline Classroom management & 8.02 & 1.63 & 1.67 & 0 & 3 \\
\hline Raising student math achievement & 7.84 & 1.30 & 1.44 & 0 & 2 \\
\hline Raising student reading achievement & 7.78 & 1.37 & 1.56 & 0 & 3 \\
\hline Role model for students & 8.40 & 1.19 & 1.50 & 1 & 2 \\
\hline Student satisfaction with teacher & 8.35 & 1.06 & 1.25 & 0 & 2 \\
\hline Parent satisfaction with teacher & 8.28 & 1.16 & 1.50 & 1 & 2 \\
\hline Positive relationship with colleagues & 7.93 & 1.64 & 1.72 & 0 & 2 \\
\hline Positive relationship with administrators & 8.43 & 1.55 & 1.55 & 0 & 2 \\
\hline
\end{tabular}

Notes: Nearly all teachers in the district are Caucasian, so race indicators are omitted. 
TABLE II

WHICH PARENTS MAKE REQUESTS?

\begin{tabular}{|c|c|c|c|c|c|c|}
\hline & \multicolumn{6}{|c|}{ Dependent Variable $=$ Fraction of Parents Making Requests } \\
\hline & $(1)$ & $(2)$ & (3) & $(4)$ & (5) & (6) \\
\hline$\%$ male & $\begin{array}{l}-0.44 \\
(0.42)\end{array}$ & & & & $\begin{array}{l}-0.29 \\
(0.25)\end{array}$ & $\begin{array}{l}-0.21 \\
(0.28)\end{array}$ \\
\hline \% eligible for free lunch & & $\begin{array}{l}-0.52 * \\
(0.13)\end{array}$ & & & $\begin{array}{l}-0.32 \\
(0.28)\end{array}$ & $\begin{array}{l}-0.54^{*} \\
(0.14)\end{array}$ \\
\hline \% minority & & & $\begin{array}{l}-0.72 * \\
(0.17)\end{array}$ & & $\begin{array}{l}-0.32 \\
(0.32)\end{array}$ & \\
\hline $\begin{array}{l}\text { \% receiving special education } \\
\text { services }\end{array}$ & & & & $\begin{array}{l}-0.34 \\
(0.55)\end{array}$ & $\begin{array}{c}0.29 \\
(0.50)\end{array}$ & $\begin{array}{c}0.49 \\
(0.42)\end{array}$ \\
\hline Number of observations & 80 & 80 & 80 & 80 & 80 & 80 \\
\hline R-squared & 0.04 & 0.37 & 0.36 & 0.02 & 0.40 & 0.39 \\
\hline
\end{tabular}

Notes: The unit of observation is a school-grade-year $(\mathrm{n}=80)$. Each column represents a separate OLS regression. All models also include grade fixed effects. Standard errors clustered at the school-year level are shown in parentheses. $*=$ significant at 5 percent level. $\dagger=$ significant at 10 percent level. 
TABLE III

FACTOR LOADINGS DERIVED FROM PRINCIPAL RATING ITEMS

\begin{tabular}{lccc}
\hline \multicolumn{1}{c}{ Item } & $\begin{array}{c}\text { Factor } 1- \\
\text { Student } \\
\text { Satisfaction }\end{array}$ & $\begin{array}{c}\text { Factor 2 - } \\
\text { Achievement }\end{array}$ & $\begin{array}{c}\text { Factor 3 - } \\
\text { Collegiality }\end{array}$ \\
\hline Dedication and work ethic & -0.132 & 0.664 & 0.165 \\
Organization & 0.004 & 0.830 & 0.013 \\
Classroom management & 0.184 & 0.827 & -0.175 \\
Raising student math achievement & -0.005 & 0.775 & 0.028 \\
Raising student reading achievement & -0.018 & 0.783 & 0.056 \\
Role model for students & 0.446 & 0.236 & 0.290 \\
Student satisfaction with teacher & 0.967 & 0.008 & 0.046 \\
Positive relationship with colleagues & 0.037 & -0.034 & 0.872 \\
Positive relationship with administrators & 0.055 & -0.026 & 0.844 \\
\hline
\end{tabular}

Notes: Factors derived from ML factor analysis with a Promax rotation that excludes the parent satisfaction item. All individual survey items are normalized. 
TABLE IV

BASELINE ESTIMATES OF PARENT REQUESTS

\begin{tabular}{|c|c|c|c|c|c|c|c|}
\hline & \multicolumn{6}{|c|}{ OLS Estimates } & \multirow{2}{*}{$\begin{array}{c}\text { Structural } \\
\text { Estimates } \\
(7)\end{array}$} \\
\hline & (1) & $(2)$ & (3) & $(4)$ & (5) & (6) & \\
\hline 2-5 years of experience & $\begin{array}{l}0.077^{*} \\
(0.026)\end{array}$ & & & & & $\begin{array}{l}0.075^{*} \\
(0.031)\end{array}$ & $\begin{array}{l}1.105 * \\
(0.493) \\
{[0.098]}\end{array}$ \\
\hline 6-10 years of experience & $\begin{array}{l}0.054 * \\
(0.021)\end{array}$ & & & & & $\begin{array}{c}0.034 \\
(0.032)\end{array}$ & $\begin{array}{c}0.876 \dagger \\
(0.494) \\
{[0.073]}\end{array}$ \\
\hline $11-20$ years of experience & $\begin{array}{l}0.085^{*} \\
(0.024)\end{array}$ & & & & & $\begin{array}{l}0.061 \dagger \\
(0.036)\end{array}$ & $\begin{array}{c}1.038 \dagger \\
(0.535) \\
{[0.089]}\end{array}$ \\
\hline $21+$ years experience & $\begin{array}{c}0.017 \\
(0.024)\end{array}$ & & & & & $\begin{array}{c}0.043 \\
(0.031)\end{array}$ & $\begin{array}{c}0.821 \\
(0.515) \\
{[0.066]}\end{array}$ \\
\hline $\begin{array}{l}\text { First year in the school (with }>1 \\
\text { year of experience) }\end{array}$ & $\begin{array}{l}-0.048^{*} \\
(0.019)\end{array}$ & & & & & $\begin{array}{l}-0.036 \\
(0.027)\end{array}$ & $\begin{array}{c}-0.424 \\
(0.398) \\
{[-0.029]}\end{array}$ \\
\hline Male & $\begin{array}{c}0.012 \\
(0.026)\end{array}$ & & & & & $\begin{array}{c}0.025 \\
(0.020)\end{array}$ & $\begin{array}{c}0.237 \\
(0.184) \\
{[0.018]}\end{array}$ \\
\hline $\begin{array}{l}\text { BA Degree at in state (but not } \\
\text { local) college }\end{array}$ & $\begin{array}{l}-0.006 \\
(0.021)\end{array}$ & & & & & $\begin{array}{l}-0.003 \\
(0.017)\end{array}$ & $\begin{array}{c}0.028 \\
(0.251) \\
{[0.002]}\end{array}$ \\
\hline $\begin{array}{l}\text { BA Degree at out of state } \\
\text { college }\end{array}$ & $\begin{array}{l}-0.020 \\
(0.027)\end{array}$ & & & & & $\begin{array}{l}-0.012 \\
(0.027)\end{array}$ & $\begin{array}{c}-0.104 \\
(0.361) \\
{[-0.008]}\end{array}$ \\
\hline MA Degree & $\begin{array}{c}0.009 \\
(0.021)\end{array}$ & & & & & $\begin{array}{c}0.026 \\
(0.021)\end{array}$ & $\begin{array}{c}0.336 \dagger \\
(0.204) \\
{[0.026]}\end{array}$ \\
\hline Any additional endorsements & $\begin{array}{l}-0.008 \\
(0.022)\end{array}$ & & & & & $\begin{array}{l}-0.018 \\
(0.017)\end{array}$ & $\begin{array}{c}-0.168 \\
(0.160) \\
{[-0.012]}\end{array}$ \\
\hline Mixed grade classroom & $\begin{array}{l}-0.067 * \\
(0.026)\end{array}$ & & & & & $\begin{array}{l}-0.028 * \\
(0.020)\end{array}$ & $\begin{array}{c}-0.483 \\
(0.326) \\
{[-0.033]}\end{array}$ \\
\hline Two teachers in the classroom & $\begin{array}{l}0.070 * \\
(0.031)\end{array}$ & & & & & $\begin{array}{l}0.042 * \\
(0.021)\end{array}$ & $\begin{array}{c}0.487 \\
(0.803) \\
{[0.040]}\end{array}$ \\
\hline Dual language classroom & $\begin{array}{c}0.024 \\
(0.033)\end{array}$ & & & & & $\begin{array}{c}0.007 \\
(0.027)\end{array}$ & $\begin{array}{c}0.849 \\
(2.884) \\
{[0.077]}\end{array}$ \\
\hline $\begin{array}{l}\text { Teacher value-added in reading } \\
\text { and math }\end{array}$ & & $\begin{array}{c}0.062 \\
(0.050)\end{array}$ & & & $\begin{array}{l}-0.025 \\
(0.041)\end{array}$ & $\begin{array}{l}-0.026 \\
(0.047)\end{array}$ & $\begin{array}{c}-0.057 \\
(0.572) \\
{[-0.004]}\end{array}$ \\
\hline $\begin{array}{l}\text { Principal's evaluation of the } \\
\text { teacher's ability to raise student }\end{array}$ & & & $\begin{array}{l}0.047^{*} \\
(0.010)\end{array}$ & & $\begin{array}{l}0.032 * \\
(0.011)\end{array}$ & $\begin{array}{l}0.024^{*} \\
(0.010)\end{array}$ & $\begin{array}{l}0.264^{*} \\
(0.109)\end{array}$ \\
\hline
\end{tabular}


achievement (composite)

[0.020]

Principal's evaluation of the

teacher's ability to promote

student satisfaction (composite)

0.055* $0.057 * \quad 0.058 *$

$0.582 *$

$(0.082)$

(0.007)

(0.009) (0.009)

[0.043]

Principal's evaluation of the

teacher's collegiality

$-0.029 *-0.026 *$

(composite)

Number of observations

$(0.011)$

$-0.191 \dagger$

$(0.108)$

[-0.014]

Chi-square (p-value) of test of

joint significance of grade fixed

251

251

251

251

251

(0.010)

331

6.00

effects in the cost function

Chi-square (p-value) of test of

joint significance of school fixed

effects in the cost function

60.91

$(0.00)$

Notes: Sample includes grades 2-6. For columns 1-6, the unit of observation is the teacher-grade-school-year $(n=251)$. The dependent variable is the number of parent requests, normalized by subtracting off the average number of requests in the grade-school-year and then dividing by the student enrollment in the grade-school-year. All models include fixed effects for school-grade-year. The fraction of parents requesting any teacher in the sample is 0.283 and the average fraction of parents requesting any individual teacher is 0.095 . Standard errors are clustered by teacher. Column 7 presents estimates of the preference parameters from the structural model. The parentheses contain standard errors that are estimated via a bootstrap and the square brackets contain the average marginal effect of the variable on each teacher's share, which is roughly comparable to the OLS point estimates. $*=$ significant at 5 percent level. $\dagger=$ significant at 10 percent level. 
TABLE V

STRUCTURAL ESTIMATES OF DIFFERENTIAL EFFECTS OF PARENT PREFERENCES BY FAMILY DEMOGRAPHICS

\begin{tabular}{|c|c|c|c|c|c|c|c|c|c|c|c|}
\hline & & $\begin{array}{c}\text { All } \\
\text { Students }\end{array}$ & $\begin{array}{l}\text { Eligible } \\
\text { for free } \\
\text { lunch }\end{array}$ & $\begin{array}{c}\text { Not } \\
\text { eligible } \\
\text { for free } \\
\text { lunch } \\
\end{array}$ & Diff. & Minority & $\begin{array}{l}\text { Non- } \\
\text { Minority }\end{array}$ & Diff. & $\begin{array}{c}\text { Bottom } \\
\text { Half of } \\
\text { Test } \\
\text { Scores } \\
\end{array}$ & $\begin{array}{l}\text { Top Half } \\
\text { of Test } \\
\text { Scores }\end{array}$ & Diff. \\
\hline & & (1) & $(2)$ & (3) & (4) & (5) & (6) & (7) & (8) & (9) & (10) \\
\hline \multirow[t]{2}{*}{$\begin{array}{l}\text { Principal Student } \\
\text { Satisfaction } \\
\text { Factor }\end{array}$} & $\begin{array}{l}\text { Structural } \\
\text { Coefficient }\end{array}$ & $\begin{array}{l}0.515^{*} \\
(0.064)\end{array}$ & $\begin{array}{l}-0.061 \\
(0.283)\end{array}$ & $\begin{array}{l}0.837 * \\
(0.195)\end{array}$ & $\begin{array}{c}-0.898^{*} \\
(0.444)\end{array}$ & $\begin{array}{l}-0.437 \\
(0.439)\end{array}$ & $\begin{array}{l}0.708^{*} \\
(0.132)\end{array}$ & $\begin{array}{c}-1.145^{*} \\
(0.530)\end{array}$ & $\begin{array}{c}-0.156 \\
(0.248)\end{array}$ & $\begin{array}{l}1.152^{*} \\
(0.259)\end{array}$ & $\begin{array}{l}-1.308 * \\
(0.432)\end{array}$ \\
\hline & $\begin{array}{l}\text { Marginal Effect } \\
\text { [Relative Effect] }\end{array}$ & $\begin{array}{c}0.039 \\
{[0.351]}\end{array}$ & $\begin{array}{c}-0.004 \\
{[-0.042]}\end{array}$ & $\begin{array}{c}0.068 \\
{[0.571]}\end{array}$ & -0.072 & $\begin{array}{c}-0.029 \\
{[-0.295]}\end{array}$ & $\begin{array}{c}0.056 \\
{[0.484]}\end{array}$ & -0.085 & $\begin{array}{c}-0.013 \\
{[-0.104]}\end{array}$ & $\begin{array}{c}0.085 \\
{[0.759]}\end{array}$ & -0.098 \\
\hline \multirow[t]{2}{*}{$\begin{array}{c}\text { Principal } \\
\text { Achievement } \\
\text { Factor }\end{array}$} & $\begin{array}{l}\text { Structural } \\
\text { Coefficient }\end{array}$ & $\begin{array}{l}0.226^{*} \\
(0.093)\end{array}$ & $\begin{array}{l}0.740 * \\
(0.271)\end{array}$ & $\begin{array}{l}-0.038 \\
(0.237)\end{array}$ & $\begin{array}{l}0.778 \dagger \\
(0.466)\end{array}$ & $\begin{array}{l}1.172 * \\
(0.430)\end{array}$ & $\begin{array}{c}0.056 \\
(0.148)\end{array}$ & $\begin{array}{l}1.116^{*} \\
(0.522)\end{array}$ & $\begin{array}{c}0.695 \dagger \\
(0.351)\end{array}$ & $\begin{array}{l}-0.058 \\
(0.300)\end{array}$ & $\begin{array}{c}0.743 \\
(0.561)\end{array}$ \\
\hline & $\begin{array}{l}\text { Marginal Effect } \\
\text { [Relative Effect] }\end{array}$ & $\begin{array}{c}0.017 \\
{[0.154]}\end{array}$ & $\begin{array}{c}0.052 \\
{[0.505]}\end{array}$ & $\begin{array}{c}-0.003 \\
{[-0.026]}\end{array}$ & 0.055 & $\begin{array}{c}0.079 \\
{[0.796]}\end{array}$ & $\begin{array}{c}0.004 \\
{[0.038]}\end{array}$ & 0.075 & $\begin{array}{c}0.057 \\
{[0.466]}\end{array}$ & $\begin{array}{c}-0.004 \\
{[-0.031]}\end{array}$ & 0.061 \\
\hline
\end{tabular}


TABLE VI

STRUCTURAL ESTIMATES OF DIFFERENTIAL EFFECTS OF PARENT PREFERENCES BY FAMILY DEMOGRAPHICS

\begin{tabular}{|c|c|c|c|c|c|c|c|c|c|c|c|}
\hline & & $\begin{array}{c}\text { All } \\
\text { Students }\end{array}$ & $\begin{array}{l}\text { Eligible } \\
\text { for free } \\
\text { lunch }\end{array}$ & $\begin{array}{c}\text { Not } \\
\text { eligible } \\
\text { for free } \\
\text { lunch } \\
\end{array}$ & Diff. & Minority & $\begin{array}{l}\text { Non- } \\
\text { Minority }\end{array}$ & Diff. & $\begin{array}{l}\text { Bottom } \\
\text { Half of } \\
\text { Test } \\
\text { Scores } \\
\end{array}$ & $\begin{array}{l}\text { Top Half } \\
\text { of Test } \\
\text { Scores }\end{array}$ & Diff. \\
\hline & & (1) & $(2)$ & (3) & (4) & (5) & (6) & (7) & (8) & (9) & (10) \\
\hline \multirow[t]{2}{*}{$\begin{array}{l}\text { Principal Student } \\
\text { Satisfaction } \\
\text { Factor }\end{array}$} & $\begin{array}{l}\text { Structural } \\
\text { Coefficient }\end{array}$ & $\begin{array}{l}0.599 * \\
(0.055)\end{array}$ & $\begin{array}{l}0.436^{*} \\
(0.211)\end{array}$ & $\begin{array}{l}0.706^{*} \\
(0.121)\end{array}$ & $\begin{array}{l}-0.270 \\
(0.307)\end{array}$ & $\begin{array}{c}0.416 \\
(0.339)\end{array}$ & $\begin{array}{l}0.648^{*} \\
(0.082)\end{array}$ & $\begin{array}{c}-0.232 \\
(0.414)\end{array}$ & $\begin{array}{c}0.195 \\
(0.240)\end{array}$ & $\begin{array}{l}1.054^{*} \\
(0.274)\end{array}$ & $\begin{array}{l}-0.859 \dagger \\
(0.465)\end{array}$ \\
\hline & $\begin{array}{l}\text { Marginal Effect } \\
\text { [Relative Effect] }\end{array}$ & $\begin{array}{c}0.045 \\
{[0.408]}\end{array}$ & $\begin{array}{c}0.030 \\
{[0.297]}\end{array}$ & $\begin{array}{c}0.059 \\
{[0.481]}\end{array}$ & -0.029 & $\begin{array}{c}0.026 \\
{[0.282]}\end{array}$ & $\begin{array}{c}0.053 \\
{[0.443]}\end{array}$ & -0.027 & $\begin{array}{c}0.017 \\
{[0.131]}\end{array}$ & $\begin{array}{c}0.079 \\
{[0.694]}\end{array}$ & -0.062 \\
\hline \multirow[t]{2}{*}{$\begin{array}{c}\text { Teacher } \\
\text { Composite Value- } \\
\text { Added Measure }\end{array}$} & $\begin{array}{l}\text { Structural } \\
\text { Coefficient }\end{array}$ & $\begin{array}{c}0.433 \\
(0.383)\end{array}$ & $\begin{array}{l}2.999 \dagger \\
(1.589)\end{array}$ & $\begin{array}{c}-1.864 \\
(1.465)\end{array}$ & $\begin{array}{c}4.863 \dagger \\
(2.850)\end{array}$ & $\begin{array}{l}6.034 \dagger \\
(3.170)\end{array}$ & $\begin{array}{l}-1.245 \\
(0.886)\end{array}$ & $\begin{array}{l}7.279 * \\
(3.410)\end{array}$ & $\begin{array}{c}0.113 \\
(1.589)\end{array}$ & $\begin{array}{l}-0.358 \\
(2.237)\end{array}$ & $\begin{array}{c}0.471 \\
(3.618)\end{array}$ \\
\hline & $\begin{array}{l}\text { Marginal Effect } \\
\text { [Relative Effect] }\end{array}$ & $\begin{array}{c}0.033 \\
{[0.295]}\end{array}$ & $\begin{array}{c}0.208 \\
{[2.046]}\end{array}$ & $\begin{array}{c}-0.156 \\
{[-1.269]}\end{array}$ & 0.364 & $\begin{array}{c}0.385 \\
{[4.095]}\end{array}$ & $\begin{array}{c}-0.101 \\
{[-0.850]}\end{array}$ & 0.486 & $\begin{array}{c}0.010 \\
{[0.076]}\end{array}$ & $\begin{array}{c}-0.027 \\
{[-0.235]}\end{array}$ & 0.037 \\
\hline
\end{tabular}


TABLE VII

DOES THE LEVEL AND VARIATION IN TEACHER QUALITY MEASURES DIFFER ACROSS SCHOOLS?

Dependent Variables

\begin{tabular}{|c|c|c|c|c|c|c|c|c|}
\hline \multirow[b]{2}{*}{ Independent Variables } & \multicolumn{4}{|c|}{ Level of Teacher Characteristics } & \multicolumn{4}{|c|}{$\begin{array}{c}\text { Range of Teacher Characteristics } \\
\text { Within Each Choice Set } \\
\text { (i.e., school*grade*year) }\end{array}$} \\
\hline & $\begin{array}{l}\text { Value- } \\
\text { Added }\end{array}$ & $\begin{array}{l}\text { Average } \\
\text { Math and } \\
\text { Reading } \\
\text { Rating }\end{array}$ & $\begin{array}{c}\text { Average } \\
\text { organization } \\
\text { and } \\
\text { management } \\
\text { rating } \\
\end{array}$ & $\begin{array}{l}\text { Student } \\
\text { Satisfaction } \\
\text { Rating }\end{array}$ & $\begin{array}{l}\text { Value- } \\
\text { Added }\end{array}$ & $\begin{array}{c}\text { Average } \\
\text { Math and } \\
\text { Reading } \\
\text { Rating }\end{array}$ & $\begin{array}{c}\text { Average } \\
\text { organization } \\
\text { and } \\
\text { management } \\
\text { rating }\end{array}$ & $\begin{array}{l}\text { Student } \\
\text { Satisfaction } \\
\text { Rating }\end{array}$ \\
\hline$\%$ eligible for free-lunch & $\begin{array}{c}0.026 \\
(0.027) \\
\end{array}$ & $\begin{array}{c}1.00 \\
(0.88) \\
\end{array}$ & $\begin{array}{c}1.47 \\
(1.15)\end{array}$ & $\begin{array}{c}1.07 \\
(0.74) \\
\end{array}$ & $\begin{array}{c}0.03 \\
(0.06) \\
\end{array}$ & $\begin{array}{l}-2.51 \dagger \\
(1.15) \\
\end{array}$ & $\begin{array}{l}-3.13^{*} \\
(0.92) \\
\end{array}$ & $\begin{array}{l}-1.30 * \\
(0.51) \\
\end{array}$ \\
\hline R-squared & 0.006 & 0.022 & 0.035 & 0.035 & 0.002 & 0.114 & 0.167 & 0.063 \\
\hline $\begin{array}{l}\text { F-stat (p-value) of joint significance of the } \\
\text { regression that includes school fixed } \\
\text { effects but no other covariates }\end{array}$ & $\begin{array}{c}0.11 \\
(1.00)\end{array}$ & $\begin{array}{c}4.66 \\
(0.00)\end{array}$ & $\begin{array}{c}5.45 \\
(0.00)\end{array}$ & $\begin{array}{c}3.29 \\
(0.00)\end{array}$ & $\begin{array}{c}1.47 \\
(0.17)\end{array}$ & $\begin{array}{c}4.35 \\
(0.00)\end{array}$ & $\begin{array}{c}2.16 \\
(0.03)\end{array}$ & $\begin{array}{c}0.99 \\
(0.46)\end{array}$ \\
\hline Number of observations & 198 & 202 & 202 & 202 & 80 & 79 & 79 & 79 \\
\hline
\end{tabular}




\section{Table VIII}

ARE REQUESTING PARENTS SIMILAR TO NON-REQUESTING PARENTS?

\begin{tabular}{|c|c|c|c|c|c|}
\hline & \multirow[b]{2}{*}{ Full district sample } & \multicolumn{2}{|c|}{ School 116} & \multicolumn{2}{|c|}{ School 122} \\
\hline & & All Students & $\begin{array}{c}\text { Students who } \\
\text { made } \\
\text { requests }\end{array}$ & All Students & $\begin{array}{l}\text { Students who } \\
\text { made requests }\end{array}$ \\
\hline$\%$ eligible for free lunch & 0.48 & 0.66 & 0.38 & 0.29 & 0.09 \\
\hline$\%$ minority & 0.27 & 0.44 & 0.24 & 0.15 & 0.06 \\
\hline \% Hispanic & 0.21 & 0.36 & 0.15 & 0.06 & 0.01 \\
\hline$\%$ other minority & 0.06 & 0.08 & 0.09 & 0.09 & 0.05 \\
\hline $\begin{array}{l}\text { \% limited English } \\
\text { proficient }\end{array}$ & 0.21 & 0.37 & 0.20 & 0.10 & 0.02 \\
\hline \% special education & 0.12 & 0.13 & 0.06 & 0.12 & 0.11 \\
\hline Number of observations & 5783 & 391 & 68 & 461 & 141 \\
\hline $\begin{array}{l}\text { Percent of parents who } \\
\text { made a request }\end{array}$ & & 0.17 & & 0.31 & \\
\hline
\end{tabular}

Notes: Sample includes all students from school 116 in 2003-04 and school 122 in 2004-05. 
TABLE IX

SENSITIVITY ANALYSES

\begin{tabular}{|c|c|c|c|c|}
\hline & \multicolumn{2}{|c|}{$\begin{array}{c}\text { Student Satisfaction Factor } \\
\text { Structural Coefficient } \\
\text { [Marginal Effect] } \\
\end{array}$} & \multicolumn{2}{|c|}{$\begin{array}{l}\text { Achievement Factor } \\
\text { Structural Coefficient } \\
\text { [Marginal Effect] }\end{array}$} \\
\hline & $\begin{array}{l}\text { Eligible for } \\
\text { Free Lunch }\end{array}$ & $\begin{array}{l}\text { Not eligible } \\
\text { for free lunch }\end{array}$ & $\begin{array}{l}\text { Eligible for } \\
\text { Free Lunch }\end{array}$ & $\begin{array}{l}\text { Not eligible } \\
\text { for free lunch }\end{array}$ \\
\hline $\begin{array}{l}\text { Baseline } \\
\text { Cost function includes grade and school fixed } \\
\text { effects. Preference function includes only } \\
\text { principal-based student satisfaction and student } \\
\text { achievement factors. }\end{array}$ & $\begin{array}{c}-0.061 \\
{[-0.004]}\end{array}$ & $\begin{array}{l}0.837 * \\
{[0.068]}\end{array}$ & $\begin{array}{l}0.740^{*} \\
{[0.052]}\end{array}$ & $\begin{array}{c}-0.038 \\
{[-0.003]}\end{array}$ \\
\hline Alternative Specifications of the Cost Function & & & & \\
\hline Include only grade fixed effects & $\begin{array}{c}-0.228 \\
{[-0.010]}\end{array}$ & $\begin{array}{l}0.692 * \\
{[0.071]}\end{array}$ & $\begin{array}{c}1.275 \\
{[0.058]}\end{array}$ & $\begin{array}{c}0.017 \\
{[0.002]}\end{array}$ \\
\hline Include school-grade-year fixed effects & $\begin{array}{c}-0.111 \\
{[-0.008]}\end{array}$ & $\begin{array}{l}0.979 * \\
{[0.077]}\end{array}$ & $\begin{array}{l}0.624^{*} \\
{[0.045]}\end{array}$ & $\begin{array}{c}-0.001 \\
{[0.000]}\end{array}$ \\
\hline $\begin{array}{l}\text { Alternative Specification of the Preference } \\
\text { Parameters }\end{array}$ & & & & \\
\hline $\begin{array}{l}\text { Includes principal-based teacher collegiality } \\
\text { factor. } \\
\text { Includes measures of experience and experience }\end{array}$ & $\begin{array}{c}-0.109 \\
{[-0.008]}\end{array}$ & $\begin{array}{l}0.980^{*} \\
{[0.080]}\end{array}$ & $\begin{array}{c}0.641 \dagger \\
{[0.045]}\end{array}$ & $\begin{array}{c}0.112 \\
{[0.009]}\end{array}$ \\
\hline $\begin{array}{l}\text { squared along with dummy variables for male } \\
\text { and MA degree as well as principal-based } \\
\text { collegiality factor. }\end{array}$ & $\begin{array}{c}-0.155 \\
{[-0.010]}\end{array}$ & $\begin{array}{l}0.915^{*} \\
{[0.075]}\end{array}$ & $\begin{array}{c}0.527 \\
{[0.034]}\end{array}$ & $\begin{array}{c}0.141 \\
{[0.012]}\end{array}$ \\
\hline Alternative Measure of Parent Requests & & & & \\
\hline Include negative as well as positive requests & $\begin{array}{c}-0.108 \\
{[-0.008]}\end{array}$ & $\begin{array}{l}0.929 * \\
{[0.077]}\end{array}$ & $\begin{array}{l}0.740^{*} \\
{[0.055]}\end{array}$ & $\begin{array}{c}-0.057 \\
{[-0.005]}\end{array}$ \\
\hline $\begin{array}{l}\text { Alternative Principal Measures } \\
\text { Using principal-reported measures of a teacher's } \\
\text { ability to promote student satisfaction and raise } \\
\text { student achievement that are by construction } \\
\text { orthogonal to the principal's report of parent } \\
\text { satisfaction }\end{array}$ & $\begin{array}{c}0.064 \\
{[0.005]}\end{array}$ & $\begin{array}{c}0.828 \dagger \\
{[0.071]}\end{array}$ & $\begin{array}{c}0.786 \\
{[0.056]}\end{array}$ & $\begin{array}{c}-0.125 \\
{[-0.011]}\end{array}$ \\
\hline $\begin{array}{l}\text { Alternative Assumption Regarding Value of Not } \\
\text { Making a Request } \\
\text { Expected teacher quality if no request is made } \\
\text { takes into account that the probability of being } \\
\text { assigned to a classroom depends on the } \\
\text { popularity of the teacher }\end{array}$ & $\begin{array}{c}-0.090 \\
{[-0.006]}\end{array}$ & $\begin{array}{l}0.722 * \\
{[0.056]}\end{array}$ & $\begin{array}{c}0.929 * \\
{[0.060]}\end{array}$ & $\begin{array}{c}-0.078 \\
{[-0.006]}\end{array}$ \\
\hline
\end{tabular}

